\title{
Výhled na Manhattan v Národním muzeu?
}

\section{Miroslava Burianová, Jiřina Dašková, Eva Dittertová \& Lucie Kodišová}

\author{
Národní muzeum, Václavské náměstí 68, 11000 Praha 1; jirina.daskova@nm.cz
}

Burianová M., Dašková J., Dittertová E. \& Kodišová L., 2020: Výhled na Manhattan v Národním muzeu? Journal of the National Museum (Prague), Natural History Series 189: 193-226.

Historická novorenesanční budova Národního muzea v čele Václavského náměstí (obr. 1) se otevřela před dvěma lety návštěvníkům po náročné, mnohaleté rekonstrukci. Výhled z veřejnosti poprvé zpř́ístupněné kopule, stejně jako zářící interiéry vstupní haly, slavnostního schodiště a Panteonu doplnily dvě mimořádné výstavy. V roce 2018 totiž současně uplynulo neuvěřitelných 200 let od založení Národního muzea a 100 let od vzniku Československé republiky. Tím naše instituce oslavila výročí dvakrát delší než naše republika. Obě tato výročí Národní muzeum uctilo výstavami - výročí republiky Československou výstavou a výročí instituce výstavou $2 \times 100$.

Výstava $2 \times 100$ představila 200 exponátů patřících mezi nejpozoruhodnější z více než 20 milionů sbírkových předmětů, které Národní muzeum opatruje a uchovává pro budoucí generace. Výběr byl podřízen snaze prezentovat nejen to nejvzácnější ze sbírek Národního muzea, ale $\mathrm{i}$ předměty veřejnosti zcela neznámé, dosud nikdy nevystavené či nově restaurované. Na první pohled nesourodý konvolut předmětů byl představen $\mathrm{v}$ překvapivém a novém kontextu, který odrážel rozmanitost exponátů historických, přírodovědných a uměleckých předmětů nejen z Čech, ale z celého světa. Pro řadu návštěvníků byla jistě nečekaná i samotná architektura výstavy - koncept „Manhattan“. Článek je věnován nejen otázkám výběru exponátů, ale je

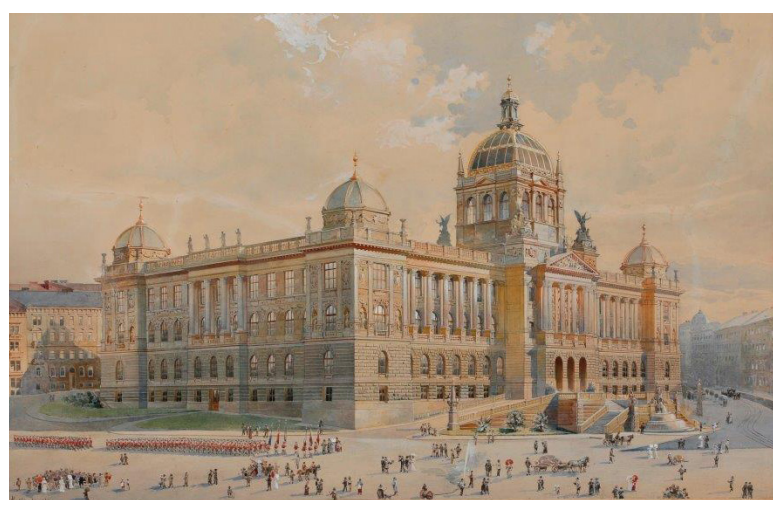

Obr. 1. Akvarel čerstvé novostavby neorenesančního paláce Muzea Království českého od architekta a profesora na České technice Antonína Balšánka (1865-1921). Budova, postupně zpřístupňovaná po slavnostním oficiálním otevření dne 18. května 1891, nebyla ještě zcela hotová. Soutěže o vnitřní malírskou a sochařskou výzdobu teprve začínaly a výroba vitrín se měla táhnout ještě dalších deset let. Foto: NM. 
i určitým vhledem do zákulisí muzejní práce: jak v náročných podmínkách probíhající rekonstrukce historické budovy vůbec výstava vznikala, jak se vyvíjelo výtvarně-architektonické řešení, proč zvítězil koncept „Manhattan“, či jaké problémy to přineslo při instalaci.

\section{0 a koncept výstavy}

Bohatství sbírek muzea je dáno nejen délkou jeho existence, ale i širokým záběrem akviziční činnosti. Uchovává historické, prrírodovědné a umělecké předměty z celého světa. Dnes tvoří Národní muzeum pětice velkých sbírkotvorných institucí - Historické muzeum, Př́rodovědecké muzeum, Náprstkovo muzeum asijských, afrických a amerických kultur, České muzeum hudby a Knihovna Národního muzea.

Někdy je význam sbírkových předmětů vyčíslitelný penězi, jindy jde o tak jedinečné nálezy, že se situace jejich objevení již nikdy nebude opakovat a určit jejich cenu je nemožné. Ta nemusí být dána jen materiálem, stářím či uměleckým zpracováním, ale i příběhem, který předmět, než se stal muzejním exponátem, prožil. Někdy jsou to dramatické osudy lidí, kteří ho v průběhu věků vlastnili, objevili či přinesli do muzea, ale i kurátorů a restaurátorů, kteří se o něj s láskou starali a starají.

Jindy př́běhy dokumentují naši historii, slavné okamžiky a události. Národní muzeum zažilo čtyři císaře a jedenáct prezidentů, monarchii, demokracii i totality. Pod jeho dohledem na horním konci Václavského náměstí se psaly dějiny 20. století. Jeho fasáda nese stopy událostí května 1945 i srpna 1968. Ostatně i svědci těchto výstřelů jsou dnes součástí muzejních sbírek.

\section{Od námětu k exponátům (anebo taky ne)}

Standardně bývá postup práce na výstavě veden v linii od vzniku námětu a tématu přes vytvoření konceptu a teprve poté jsou vybírány předměty. Námět samozřejmě vychází ze znalosti muzejních sbírek, avšak téma je tím, co samo o sobě tvoří myšlenkový základ výstavy.

Najít společného jmenovatele pro pět muzeí nebylo snadné. Výstava $2 \times 100$ proto začala vznikat $\mathrm{z}$ druhého konce - od předmětů. Desítky kurátorů muzejních sbírek navrhovaly výjimečné artefakty, u některých bylo již od začátku jasné, že na výstavě nemohou chybět, avšak k definitivnímu stanovení kritérií výběru vedla dlouhá cesta. $\mathrm{V}$ posledních letech jsou ve světě populární výběry sbírkových předmětů pro výstavu učiněné nějakou osobností. Ostatně i v České republice tzv. Director's Choice úspěšně zvolilo pražské Uměleckoprůmyslové museum. To ovšem opatruje jen umělecké sbírky. V Národním muzeu bylo třeba vybrat výjimečné předměty ze sbírek pěti naprosto různorodých muzeí.

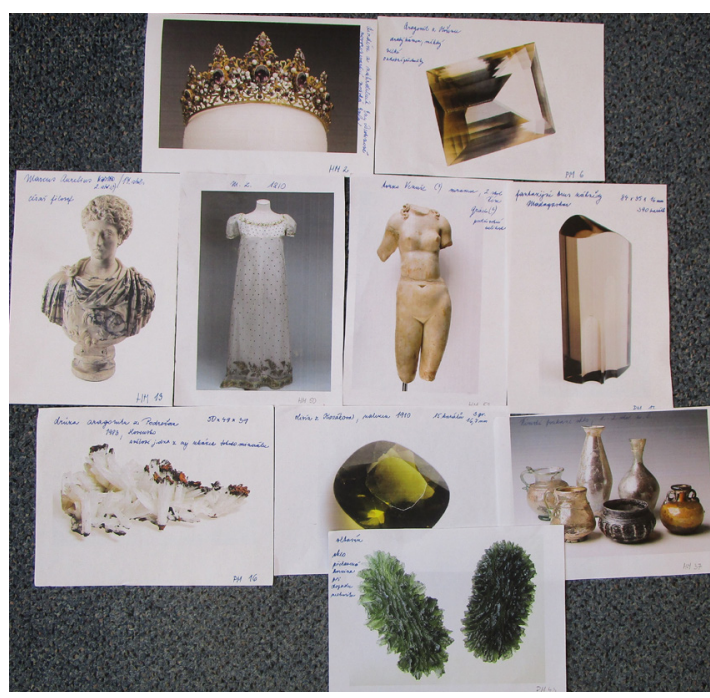

Obr. 2. Kurátoři jednotlivých sbírek poskytli návrhy předmětů pro jednotlivá témata. $Z$ nich pak autorky provedly užší výběr. Na pracovní fotografii jsou předměty $\mathrm{k}$ tématu Křehké $a$ věčné. Foto: $M$. Burianová. Pospojovat je ve smysluplný celek a dát tak výstavě další rozměr byla výzva. I proto vznikl autorský tým napříč institucí - z Přírodovědeckého, Historického a Náprstkova muzea. 
Autorky vybíraly ${ }^{1}$ mezi předměty, které jsou jako ty největší poklady vystavovány opakovaně, ale i předměty veřejnosti zatím zcela neznámými, které např́klad byly teprve nedávno získány do sbírek. Další skupinou byly předměty, které nebyly nikdy vystaveny z důvodu špatného stavu, ale byly nedávno restaurovány za použití mimořádných technologií a postupů.

Cílem bylo najít hlubší souvislosti než jen příslušnost ke konkrétní sbírce a vědnímu oboru (což je nejběžnější způsob z hlediska práce kurátorů), materiál (což je nejběžnější způsob z hlediska péče o sbírky a instalace), nebo původ (aktuální téma mapující osudy původních majitelů předmětů). Bylo potřeba najít artefakty, které spolu souvisejí ve více rovinách a které dokážou vytvořit překvapivé téma díky na první pohled neviditelným, či naopak zcela zjevným vztahům. Procházely jsme stovky unikátních předmětů, při každém dalším návratu $\mathrm{k}$ fotografii či příběhu přibývalo souvislostí a předměty spolu začaly náhle vést dialog.

Prvním exponátem, který takto začal „konverzovat" s dalšími sbírkovými předměty Národního muzea, byly dosud nikdy nevystavené svatební šaty Marie Luisy, manželky Napoleona I. Bonaparta. Jejich subtilnost a přitom

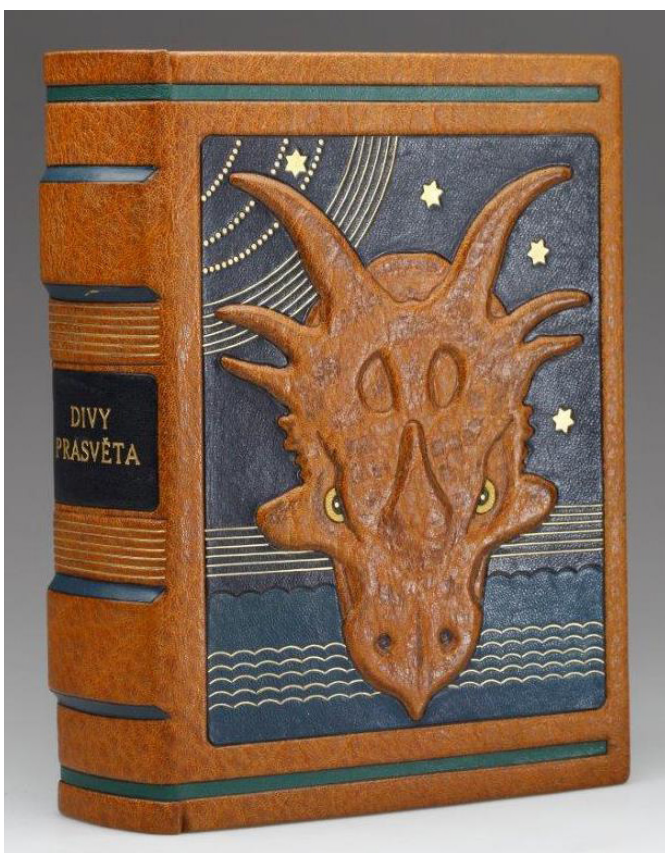

Obr. 3. Kniha Divy prasvěta paleontologa Josefa Augusty (1903-1968) z roku 1942 byla jednou z prvních odborných publikací zaměřujících se na studium pravěku. Text dopInil ilustracemi Zdeněk Burian (1905-1981). Umělecká knižní vazba z roku 1947 zachycuje hlavu dinosaura rodu Styracosaurus. Podle Burianova návrhu ji zhotovil jaroměřský knihař Josef Hodek (1892-1968) a použil na ni barvenou sloní kůží doplněnou plastickou aplikací a zlacením. Foto: J. Vaněk. nadčasovost přímo vybízely k vystavení s drahokamy, sklem, antickými sochami či šperky (obr. 2). Druhým takovým exponátem byla kniha Divy prasvěta Josefa Augusty s ilustracemi Zdeňka Buriana (obr. 3). Nádherný umělecký svazek vázaný ve sloní kůži dokonale harmonoval s unikátními paleontologickými sbírkami - s nejslavnějším českým dinosaurem Burianosaurus augustai nebo trilobitem s dochovanou trávicí trubicí či nejstarším na světě doloženým nálezem rostlinné zkameněliny.

Některé souvislosti odkazovaly ke konkrétnímu historickému období či stejnému sociokulturnímu fenoménu, v jiných byl výběr podřízen snaze o hledání zajímavých, nezvyklých a nových vztahů. Vnitřní obsah, estetické podobnosti a neznámé příběhy tvořily další hlubší souvislosti i rozpory. Témata tak v sobě propojovala nejen určitou harmonii, ale i ambivalenci. Meteorit se mohl stát symbolem apokalypsy, stejnokroj války a zároveň míru, náhrdelník nenaplněných ambicí, sklo a drahokamy mohly spojovat křehkost s věčností, had symbolizovat vyhnání z ráje - od Boha do světa hříchu - a kámen nést poselství našich předků stejně jako papír. Každý vybraný předmět mluví nejen sám za sebe, ale vede také rozhovor s ostatními předměty, čímž vytváří obraz hlubšího smyslu muzejních sbírek.

1 To tvrdé „y", které se v textu občas objevuje, je správně, nebot' autorský tým tvořily ženy - paleontoložka Jiřina Dašková, historička Miroslava Burianová, ředitelka Náprstkova muzea Eva Dittertová, kunsthistorička Lucie Kodišová a produkční Kateřina Kočí. 


\section{Architektura a grafika}

\section{Proč Manhattan...}

Cesta k finální podobě expozice byla komplikovaná, protože v historické budově byla rekonstrukce stále v plném proudu. Ještě na počátku roku 2018 nebylo jasné, které prostory bude možné v předčasném termínu oproti plánu dokončit. Teprve v březnu padlo konečné rozhodnutí, že výstava bude umístěna v budoucích přednáškových sálech v přízemí historické budovy. Rekonstrukce ovšem stále probíhala a o to složitější práce byla.

Během př́iprav a realizace se proto postupně proměňoval i architektonický návrh celé výstavy. Původnímu návrhu se nejvíce přibližuje tzv. „stěna zakladatelů“ (viz dále) - předměty měly být umístěny po skupinách v trezorových vitrínách ukrytých ve stavbě tak, aby návštěvník mohl přijít až ke sklu a zblízka si všechny exponáty prohlédnout. Zatímco návštěvník by stál ve stř̌edu, jedinečné předměty by ho obklopily ze všech stran. Koncept architektky Emílie Jarošové vycházel z myšlenky tzv. kabinetu kuriozit. Mladá talentovaná architektka se inspirovala u historických muzejních expozic z 19. století. Nesourodost exponátů tomuto, dnes překonanému, způsobu vystavení muzejních sbírek velmi dobře konvenovala. Emília Jarošová mu navíc vtiskla osobitý elegantní design. Při pohledu návštěvníka na instalované předměty by zůstal zachován mozaikový vzhled, kdy návštěvník by viděl všechny předměty $v$ tématu současně. Zároveň však měl být každý předmět vystaven v samostatné vitríně tak, aby byla jeho výjimečnost podtržena i individuální instalací (obr. 4, 5). Bohužel toto výtvarně-prostorové řešení nemohlo být z již naznačených důvodů realizováno. Tento úplně první návrh architektury Emílie Jarošové vzal $\mathrm{z}$ drtivé většiny za své právě proto, že v průběhu př́íprav a komunikace s architektkou stále nebyly dořešeny některé stavební problémy (např. protipožární zabezpečení, únikové cesty, změny $\mathrm{v}$ termínech dokončovacích prací). Uprostřed tvorby výstavy tedy bylo nutné přejít $\mathrm{k}$ novému řešení, které Emília Jarošová vymyslela doslova přes noc. Zásadním problé-

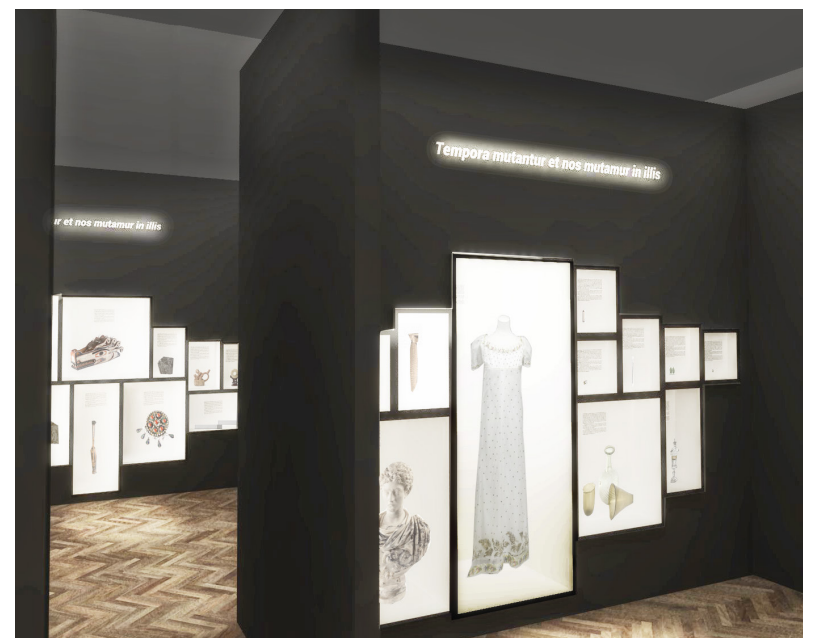

Obr. 4. Vizualizace prvního návrhu výstavy. Autorka: E. Jarošová.

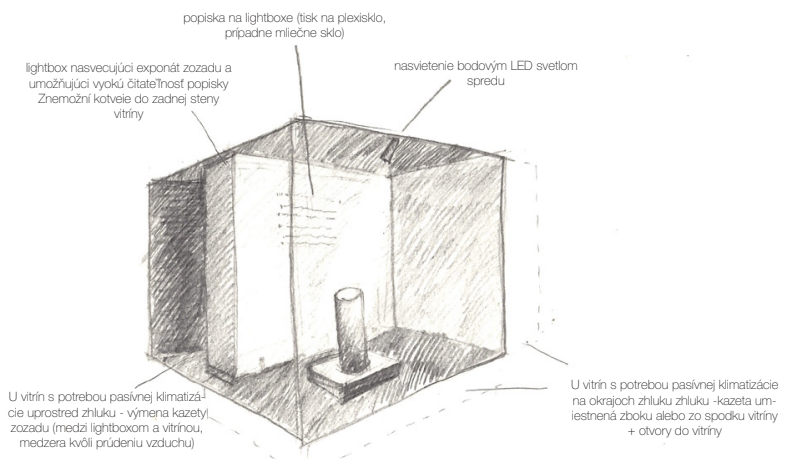

Obr. 5. Nerealizovaný princip vystavení exponátů: na zadní stěně vitríny je umístěn světelný box s popiskami, vitríny mají pasivní klimatizaci a předměty jsou nasvíceny bodovým LED světlem. Autorka: E. Jarošová. 
mem byla bezpečnost předmětů. Vzhledem k tomu, že již nebylo možné z časových důvodů (nadlimitní zakázka) použít trezorové vitríny, bylo třeba nalézt stejně účinný bezpečnostní prvek. Nová myšlenka vycházela ze skutečnosti, že milionové hodnoty bývají uchovávány $\mathrm{v}$ trezorech za mřížemi. I mezi muzejními artefakty byly takové, jejichž pojistná hodnota byla vyčíslena na desítky milionů korun. Proto architektka zvolila instalaci, kdy trezorem se stal celý středový prostor sálu, ukrytý za bezpečnostním mř́ížovím (obr. 6). Některé původní myšlenky zůstaly zachovány, například samostatné vitríny zhotovené na míru pro každý exponát, tj. přesně 200 vitrín. S ohledem na výjimečnost artefaktů musela mít každá vitrína vlastní regulovatelné osvětlení a vlhkost. Teplota byla pro výstavní sály nastavena centrálně.

Jiné prvky z původního architektonického návrhu už ale zachovány být nemohly. Vzhledem k menšímu prostoru, který střed sálů (oproti konceptu vitrín rozmístěných po obvodu sálů) poskytoval, bylo třeba předměty umístit vertikálně. Aby byly všechny vidět, volila architektka více výškových úrovní. Velké, a tedy dobře viditelné předměty byly umístěny do pozadí a do výšky, menší předměty dopředu, blíže k návštěvníkovi, do ideální pohledové výšky (obr. 7). Každý předmět dostal tzv. věžovou vitrínu a komplet soklu a skla tak tvořil samostatně stojící "mrakodrapy“. Proto architektka Jarošová nazvala koncept Manhattan.

Kovové mřížoví se skládalo z ocelových, obdélníkových profilů, takže při pohledu do stran tyto „lamely“ bránily návštěvníkovi rozptylovat se pohledem na sousední téma. Lamely mu jednotlivá témata odkrývaly postupně, jak procházel sálem. Ve chvíli, kdy návštěvník stanul před tématem, čelní pohled mu umožnil obsáhnout celé téma, které se mu tak zcela odkrylo, jedním pohledem (obr. 11, 12, 34).

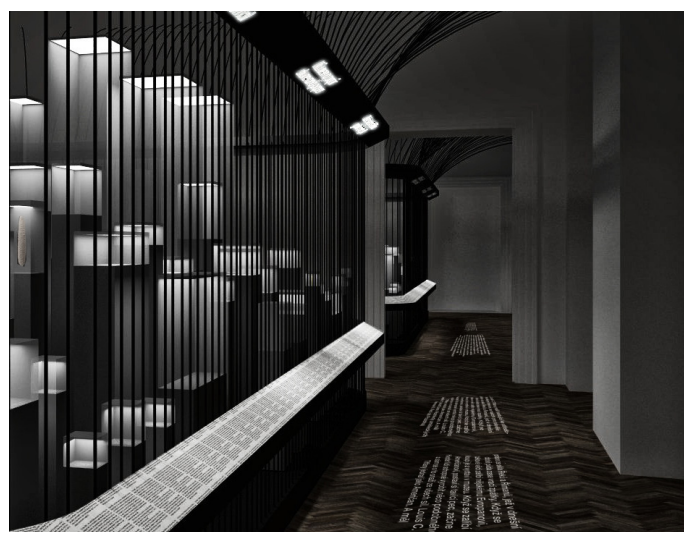

Obr. 6. Jeden z prvních návrhů mřižoví s použitím jeklů. Na návrhu jsou patrné i texty promítané na zem (nebylo realizováno). Autorka: E. Jarošová.

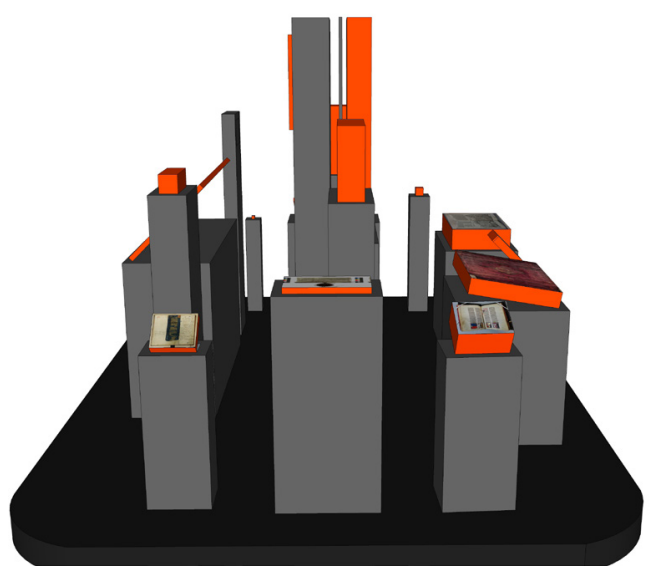

Obr. 7. Vizualizace rozmístění vitrín a předmětů. Autorka: E. Jarošová.

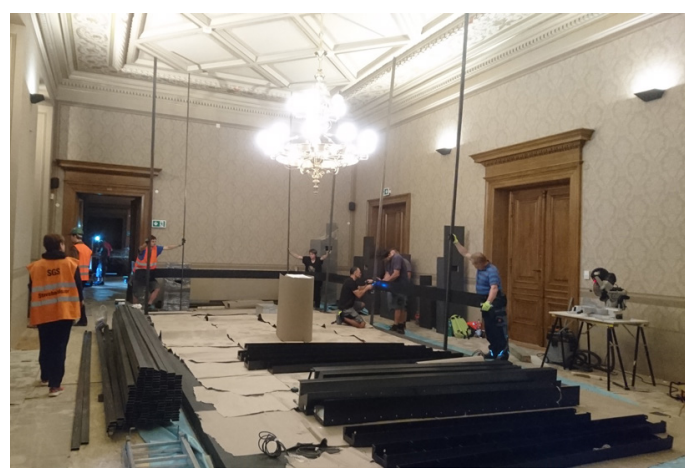

Obr. 8. První dny stavby výstavy. Foto: J. Dašková. 


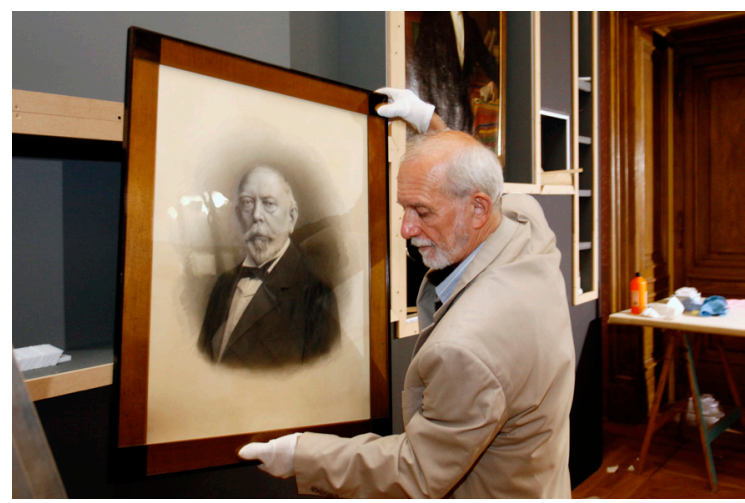

Obr. 9. Kurátor sbírky obrazů Lubomír Sršeň během instalace portrétu architekta budovy Národního muzea Josefa Schulze. Foto: J. Vaněk.
Nad věžemi vitrín pak zářil neonový nápis s názvem tématu. Popisky byly umístěny na obvodu trezoru v lightboxech (plastové, mléčně zbarvené a podsvícené desky, na které byly nalepeny popisky vytištěné na průhledné fólii). Na lightboxech byl pro lepší orientaci název tématu zopakován a doplněn citátem vystihujícím souvislosti v tématu. Slova vědců, umělců, politiků či spisovatelů uvozovala každý celek. Souznění předmětů v každém tématu bylo částečně založené na pocitech, vizuálnosti a př́bězích konkrétních exponátů, proto vy-

světlujících úvodních textů nebylo třeba. 0 preferenci rozšířených popisků před textovými panely rozhodla výjimečnost exponátů. Výlučnost každého předmětu tak byla zdůrazněna i skutečností, že mu byl věnován výkladový popisek, vysvětlující jeho jedinečnost. Orientaci usnadnila grafika - kreslené ikonky předmětů na každém popisku. Velký prostor pak dostala grafika na tzv. branách (viz dále).

\section{Instalace a tři dny s rakví}

Ve všech sálech byla nejdříve postavena vyvýšená pódia, pod kterými byla ukryta veškerá technika. Následovala stavba mřížoví (obr. 8) a do každého takto vzniklého výstavního prostoru byl ponechán jen vchod nutný pro umístění vitrín a instalaci samotných předmětů. Akce byla logisticky i technicky velmi náročná, protože stavba musela probíhat od středu - od největších vitrín po krajní, menší. Současně s instalací vitrín, zapojováním světel apod. byly přiváženy předměty, které nesměly zůstat nezabezpečené. Jejich instalace většinou probíhala $\mathrm{v}$ den, kdy byly transportovány. Kurátoři předměty k převozu připravovali několik dní předem a svozy byly rozplánovány doslova na dny a hodiny, protože svou roli hrály nejen rozměry a umístění předmětů (depozitáře na různých místech ČR), ale i pojistná hodnota. Někdy se $v$ automobilu mohl převážet jeden jediný předmět, v jiných případech i několik. Pro artefakty citlivé na změny teploty a vlhkosti byly vyrobeny speciální „klimabedny“.

Logistika instalace obnášela synchronizaci stavby soklu, transportů a instalace. Samotná instalace předmětu probíhala za přítomnosti kurátora předmětu, odborného restaurátora, komisařky výstavy, produkční, minimálně jedné autorky výstavy, aranžérky a samozřejmě zástupců stavby, kteří okamžitě vitrínu po umístění předmětu zasklívali. Ve výjimečných př́ípadech předměty čekaly na okamžik instalace

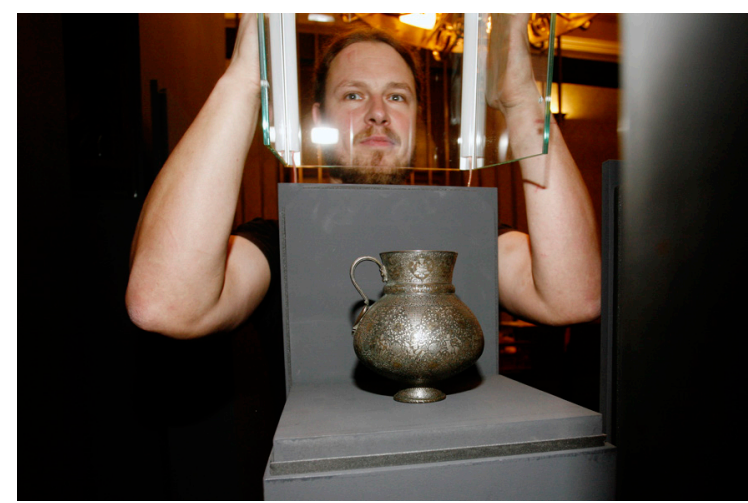

Obr. 10. Václav Kulda (DKset, s. r. o.) zasklívá džbánek na vodu. Džbánek z Blízkého východu byl vytvořen mosulským řemesIníkem v 1. polovině 13. století. Rostlinné, geometrické a figurální motivy s astrologickou symbolikou jsou vykládány stř́brem a zlatem. Foto: J. Vaněk. 


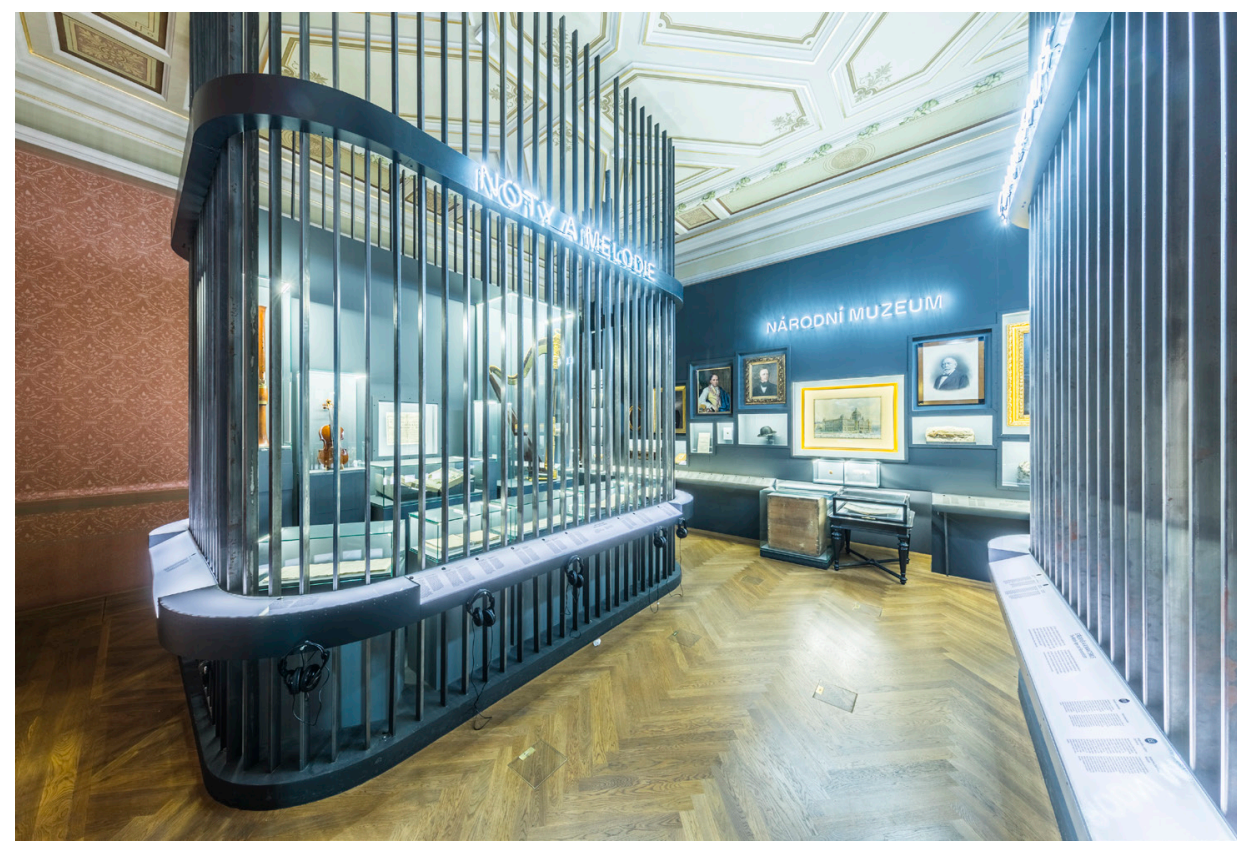

Obr. 11. Pohled při vstupu do prvního výstavního sálu. Vlevo exponáty v tématu Noty a melodie, vpravo Středověk a romantismus, naproti vstupním dvěřím je stěna věnovaná zakladatelům a exponátům $s$ inv. číslem 200. Před stěnou zakladatelů je $\mathrm{k}$ vidění tzv. Jirušova bedna, vpravo od ní pak vitrína navržená architektem J. Schulzem. Foto: M. Frouz.

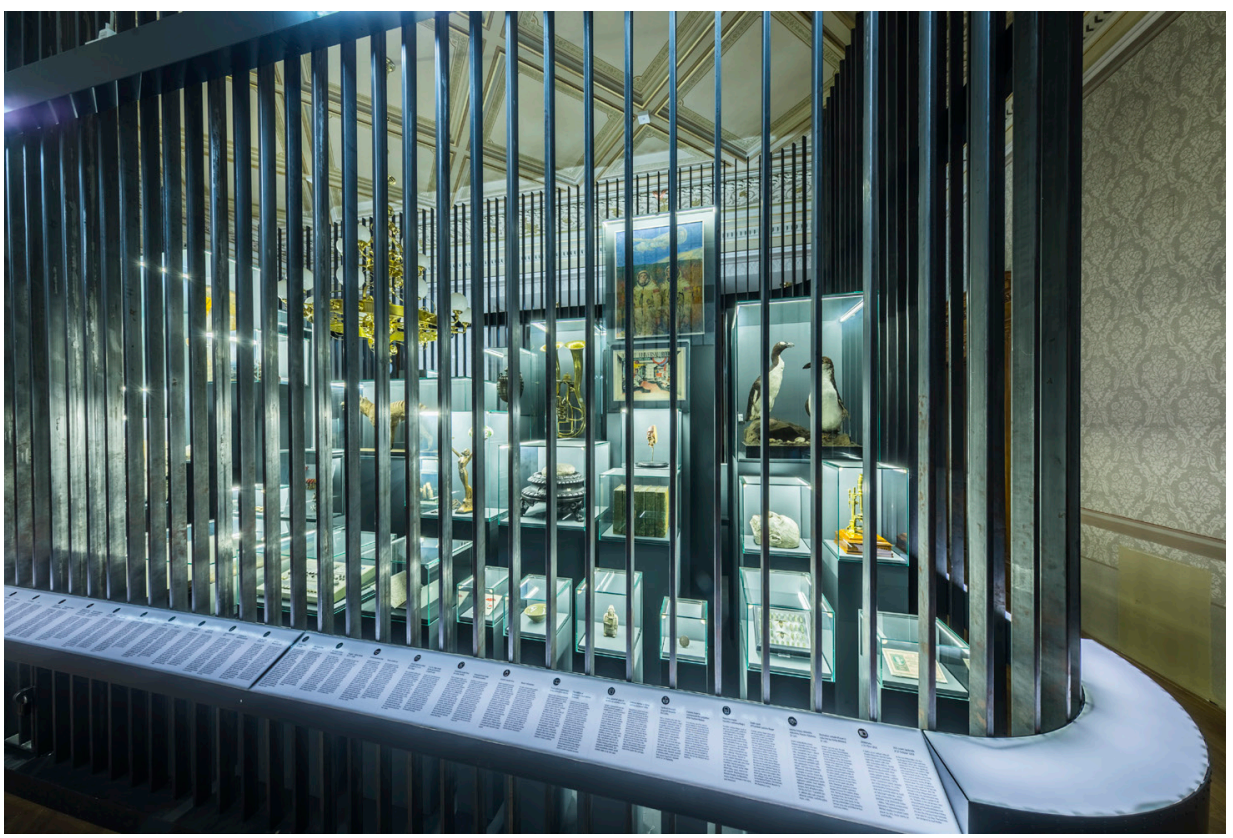

Obr. 12. Část výstavy věnovaná tématu Pokrok a zánik ve třetím výstavním sálu, vpravo nahoře jsou umístěny dermoplastické preparáty dvou exemplářu alky velké, vyhubené člověkem. Foto: M. Frouz. 
v trezoru. Nejcennější předměty až do okamžiku uzamčení vitríny a zapojení bezpečnostních prvků doprovázela ochranka.

V některých místech se postupovalo poměrně rychle, ale např́íklad instalace egyptské rakve byla realizována týmem po dobu celých tří dnů. Občas bylo až k neuvěření, že i před půlnocí byli pánové z obou realizačních firem (LN-Design, s. r. o., DKset, s. r. o.) ochotni (a s úsměvem) zkracovat sokl vitríny o deset centimetrů tak, aby nebránila v pohledu na vitrínu za ní.

Mimořádná pozornost byla věnována i samotné instalaci předmětů do vitrín. Instalační prvky byly vyrobeny na míru každému předmětu, většinou z „neviditelného“ čirého plexiskla. Cílem bylo, aby návštěvník vnímal předmět bez jakýchkoli rušivých momentů. Tomu napomáhalo i lokální svícení každého předmětu samostatně. Zatímco výstavní sály se halily do šera, předměty, u kterých to jejich materiál a stav umožňovaly, zářily. Bohužel velký zájem o výstavu přinesl i problém jejího prodlužování. Původně plánované tř̌i měsíce se nakonec protáhly na měsíců osm. U některých předmětů, především textilních a papírových, bylo přitom plánováno je v polovině konání výstavy vyměnit za jiné. Díky prodloužení nakonec místo jedné výměny musely proběhnout výměny tři. $V$ architektonickém návrhu bylo s výměnou během konání výstavy počítáno. Problematické ovšem bylo vybrat další předměty. Muselo se jednat o mimořádné artefakty, které svým př́iběhem a obsahem korespondovaly s tématem a shodovaly se i ve velikosti, nebot' vitríny byly vyráběny předmětům na míru. Vzhledem k prodloužení doby vystavení musela být u předmětů, které nebylo možné vyměnit, snížena intenzita osvitu.

\section{Sedm bran}

Mimořádné předměty mají často zajímavé příběhy. I když byly popisky rozšířené na 900 znaků, což odpovídá kratším výstavním textům, stále to nebyl dostatečný prostor, aby tyto mimořádné příběhy postihl. Někdy se s předměty pojily záhady, které odborníci rozklíčovávali dlouhá desetiletí. Někdy to byly příběhy osudové, spojené s dějinami naší země, českého národa i týkající se významných osobností. Protože samotné výstavní sály byly zamýšleny jako čistý prostor, věnovaný skutečně jen a jen předmětům, padlo rozhodnutí využít i dlouhou přístupovou chodbu, táhnoucí se podél všech tří výstavních sálů.

Vzhledem ke skutečnosti, že tudy návštěvníci do výstavy přicházeli, stala se tak chodba jakýmsi vizuálně informačním úvodem výstavy (obr. 13-15). Na sedmi branách, za kterými se vstupovalo do prvního sálu výstavy, se objevily doplňující informace $\mathrm{k}$ exponátům. Představena zde byla práce kurátorů, amatérských sběratelů, velkorysost donátorů, nejnovější závěry vědců, mimořádné restaurátorské postupy či téměř románové osudy původních majitelů apod. Některé drobné předměty si návštěvníci mohli prohlédnout i díky působivé grafice Jáchyma Šerýcha v několikanásobné zvětšenině.

I $\mathrm{v}$ případě řešení podoby celé chodby nastaly podobné obtíže jako $s$ architekturou celé výstavy, opět $\mathrm{z}$ výše uvedených důvodů. Změny v návrhu architektonického řešení se naštěstí netýkaly samotných bran, ale závěru chodby. Na jejím konci mělo být podle původního plánu umístěno plátno. Audiovize měla

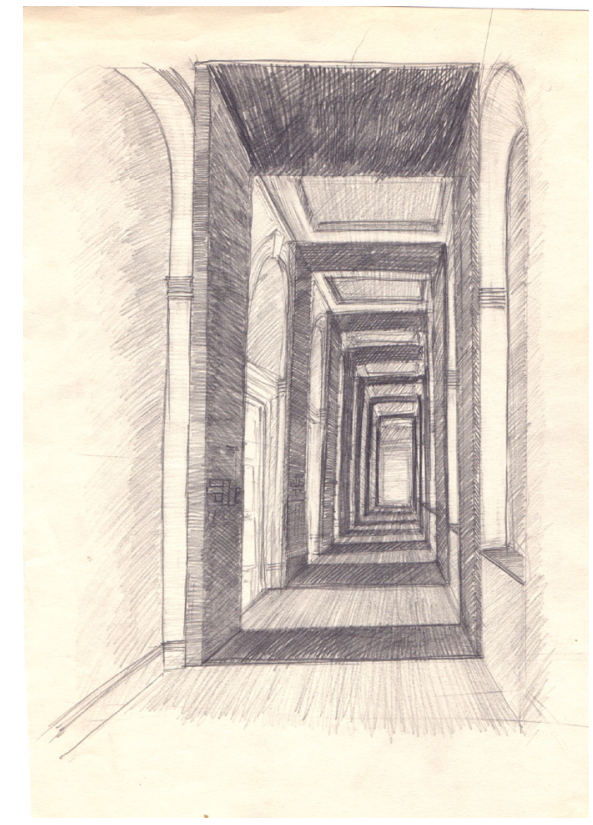

Obr. 13. Návrh podoby vstupní chodby. Autorka: E. Jarošová. 


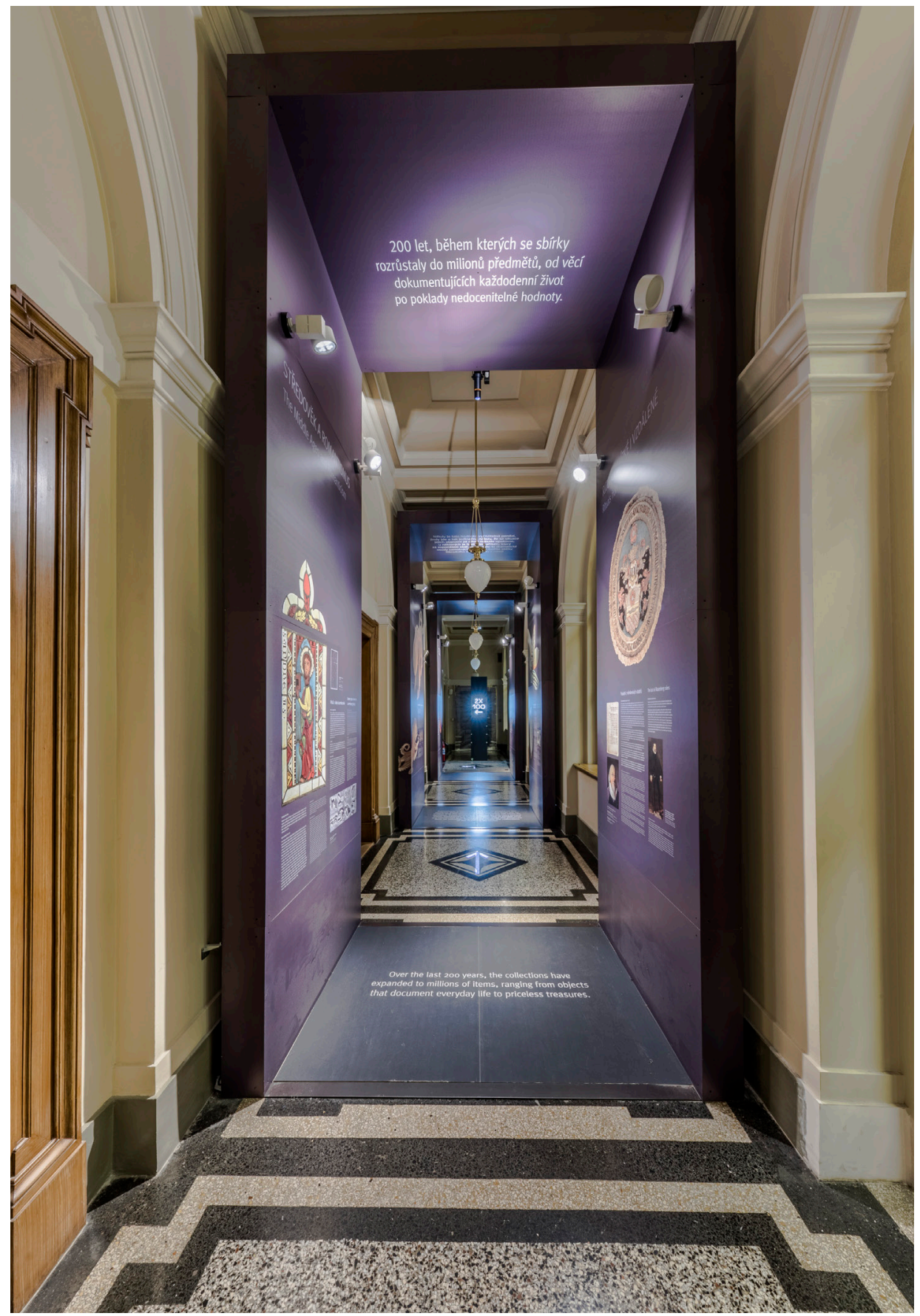

Obr. 14. Vstupní chodba s branami, na kterých byly k vybraným předmětům prezentovány detailnější informace, týkající se například historie předmětů, práce restaurátorů, životních osudů původních majitelů či donátorů sbírkových předmětů. Na bráně na fotografii je vlevo vidět fotografie vitráže ze 14. století, vpravo pohřební štít Petra Voka z Rožmberka. Texty byly v celé výstavě dvojjazyčné (česky a anglicky). Foto: M. Frouz. 


\section{KÁMEN A PAPÍR}

\section{Stone and paper}

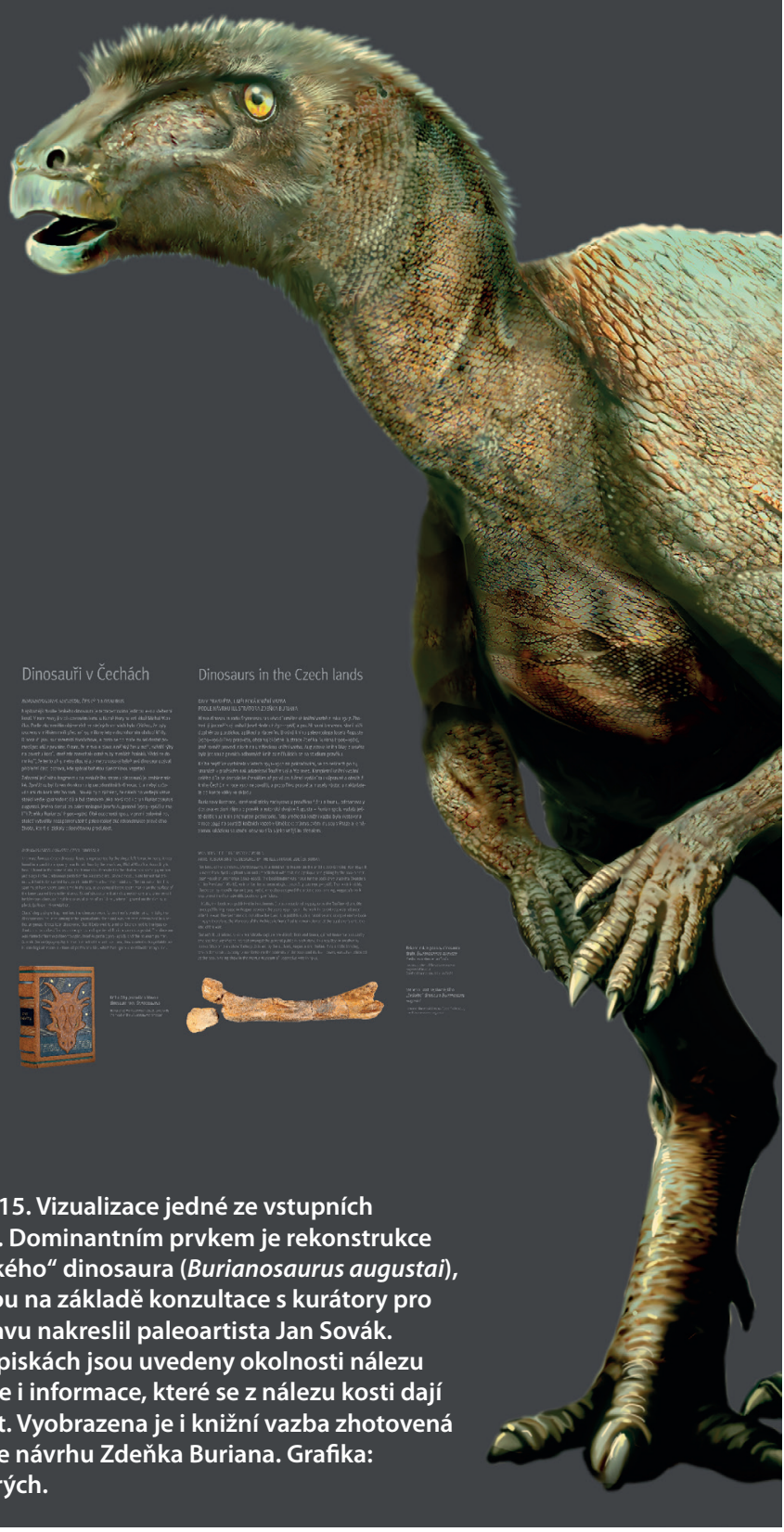


představit život Historické budovy Národního muzea, která se od počátků filmové tvorby stala opakovaně „hvězdou stř́brného plátna“. Monumentální budova se i díky umístění na nejvýznamnějším pražském náměstí stala kulisou řady filmových záběrů z desítek filmů i veřejného života. $\mathrm{K}$ nejvtipnějším patřila sekvence $\mathrm{z}$ bollywoodského snímku Duplicate (1998) s hvězdným Shahkrukh Khanem, zpívajícím a tančícím na schodech před budovou Národního muzea. Ostatně dodnes se v působivých interiérech historické budovy natáčejí i zahraniční snímky, jako např́ílad Mission: Imposible (1996), Euro Trip (2004), bondovka Casino Royale (2006), nebo seriál Boj o těžkou vodu (2015). Připravily jsme rozsáhlou rešerši filmových děl, vytipovaly jednotlivé záběry, produkční začala jednat o autorských právech a výslednou podobu měl tomuto nápadu dát cenami ověnčený Luděk Hudec. Bohužel od celého záměru muselo být z požárněbezpečnostních důvodů zcela upuštěno.

\section{Procházka výstavou}

Všechny exponáty jsou již uložené v depozitářích Národního muzea. Některé z nich budou moci návštěvníci obdivovat ve stálých expozicích, které Národní muzeum postupně zpřístupní od roku 2021, avšak možnost vidět je všechny společně se návštěvníkům již sotva naskytne.

Vrat'me se tedy zpět do výstavy a představme si, že ji spolu s autorkami znovu procházíme. Začneme v monumentální chodbě (každá brána měřila na výšku přes čtyři metry) a vstupujeme do prvního sálu. Půjdeme téma po tématu, od úvodní stěny věnované osobnostem Národního muzea (obr. 17), kterou v sále doplňují celky Středověk a romantismus a Hudba a melodie, oba hluboce provázané s historií národa i instituce v 19. století, až po poslední, dvanácté téma.

\section{Stěna zakladatelů}

„Svatý budiž ústav tento národu - jeho založení národní slavností, každý nějakou obět' na oltár národnosti přinášej." (Josef Jungmann)

V samotném úvodu výstavy vítaly návštěvníky symboly instituce. Jejími pilírí jsou sbírky. Jsou tím nejdůležitějším, co ukrývá budova, která je pro ně vzácnou schránkou. A život těmto dvě-

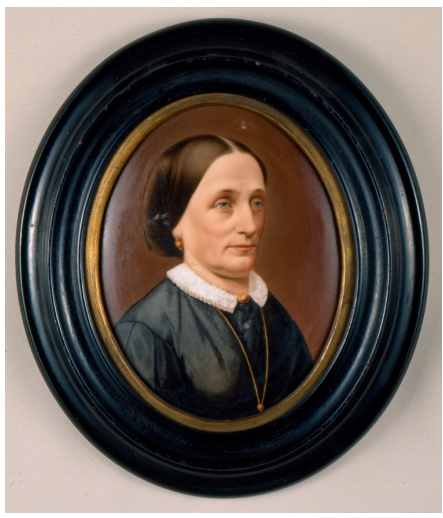

Obr. 16. Josefa Náprstková (1838 až 1907). Portrét vytvořil v roce 1877 Jan Zachariáš Quast (1814 až 1891) technikou malby na porcelán. Quast se na tuto techniku specializoval a jeho práce často předčí technickou dokonalostí v té době se rozmáhající fotografické portréty. Foto: J. Vaněk. ma vtiskují lidé. Sbírky, budova a lidé (at' už zakladatelé, zaměstnanci, donátoři, či návštěvníci), to je Národní muzeum.

Dvě stě let života Národního muzea bylo ohraničeno roky 1818 a 2018. Prvním symbolem byl pečetní typář se znakem instituce. Ačkoli pochází skutečně z roku 1818, obraz na pečetní ploše je aktuální dodnes, nebot' je součástí současného muzejního loga. Diadém Sbírka pak představoval artefakt o dvě stě let mladší. Vznikl jako pocta českého šperkaře Hanuše Lamra Národnímu muzeu a jeho uměleckým a př́rodovědným sbírkám (obr. 18). Tento umělecký objekt byl tvaroslovím inspirován vzácnou románskou čelenkou ze sbírky Oddělení starších českých dějin (obr. 32), ale jeho dekor vycházel z aktuální tvorby Hanuše Lamra, která přetváří do šperků přírodní vzory. 0 tom, že sbírky mohou ukrývat nejedno tajemství, svědčila vystavená, poněkud nevzhledná, ale o to záhadnější, Jirušova bedna. Jednatel Společnosti Muzea Království českého a donátor jeho sbírek MUDr. Bohuslav šlechtic Jiruš nechal uložit do dvou dřevěných beden, vyložených zinkovým plechem, neznámé předměty pro sbírky Národního muzea s pod- 


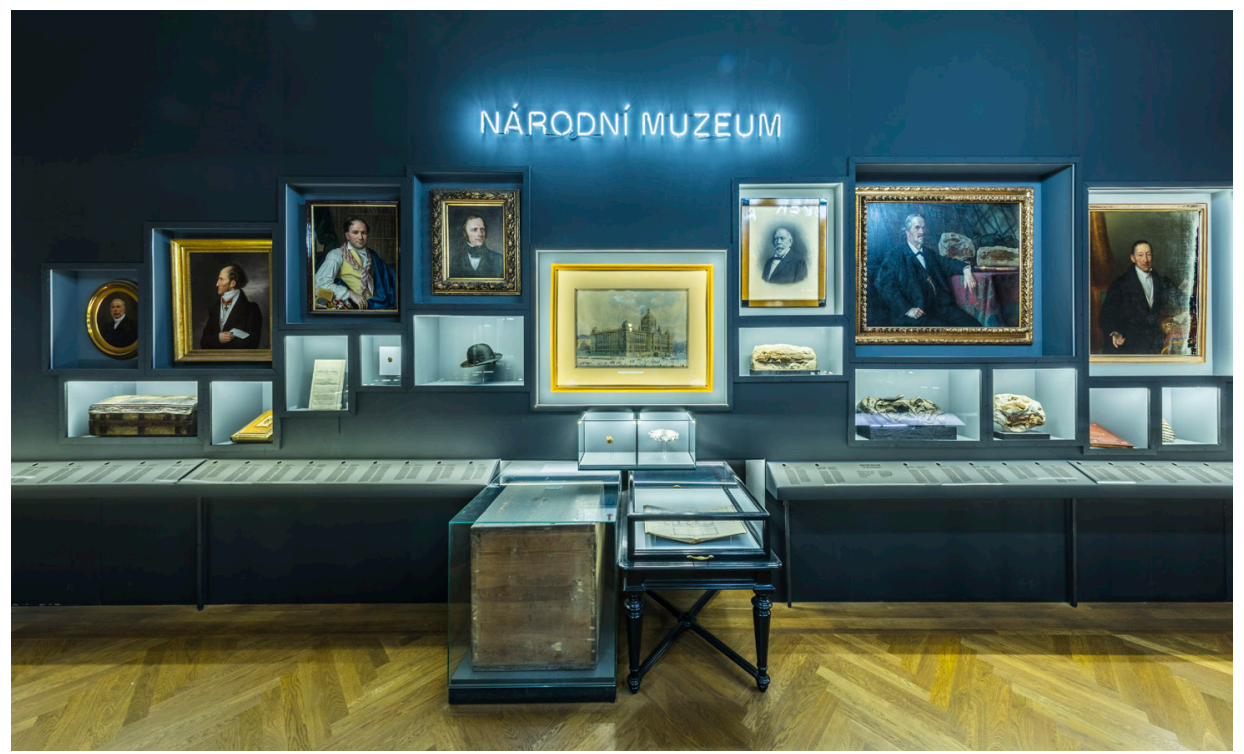

Obr. 17. Stěna zakladatelů, pod obrazem nově postavené budovy Národního muzea je první razítko, které bylo v muzeu používano, a diadém Sbírka, který k 200. výročí muzea vytvořil šperkař Hanuš Lamr. Foto: M. Frouz.

mínkou, že bedny smějí být otevřeny až 200 let po jeho smrti. Tento okamžik nastane až v roce 2101 . Do té doby je obsah beden zahalen tajemstvím, nebot' soupis toho, co bedny obsahují, neexistuje, a muzejníci přání donátora respektují.

Od roku 1891, kdy byla Historická budova Národního muzea zpřístupněna veřejnosti, představuje hlavní sídlo instituce. V roce 1893 vytvořil Antonín Balšánek akvarel, který je nepochybně nejpůsobivějším vyobrazením tehdy zcela čerstvé novostavby (obr. 1). Architektem budovy byl Josef Schulz (obr. 9), kterým se dostáváme k poslednímu pilíri instituce, a tím jsou osobnosti.

Bez výjimečných osobností by Národní muzeum vzniknout nemohlo. Prostřednictvím portrétů bylo představeno osm nejvýznamnějších. Zmiňovaný architekt Josef Schulz navrhl reprezentativní neorenesanční palác, veškerý muzejní mobiliář, kreslil i návrhy na škrabku na boty u vstupních dveř́ či na krytky klíčových dírek. $\mathrm{V}$ anonymní soutěži zvítězil nad 26 konkurenty i díky myšlence Panteonu, jakéhosi chrámu osobností vědy, kultury i politiky.

Za datum vzniku Národního muzea tehdy Vlastenského muzea (Vaterländisches Museum) - je považován 15. duben 1818, kdy zemská vlastenecká šlechta schválila návrh na zřízení nového muzea a předložila ho k podpisu nejvyššímu purkrabímu Františku Antonínovi hraběti Libštejnskému z Kolovrat. Návrh provolání vypracoval František Josef

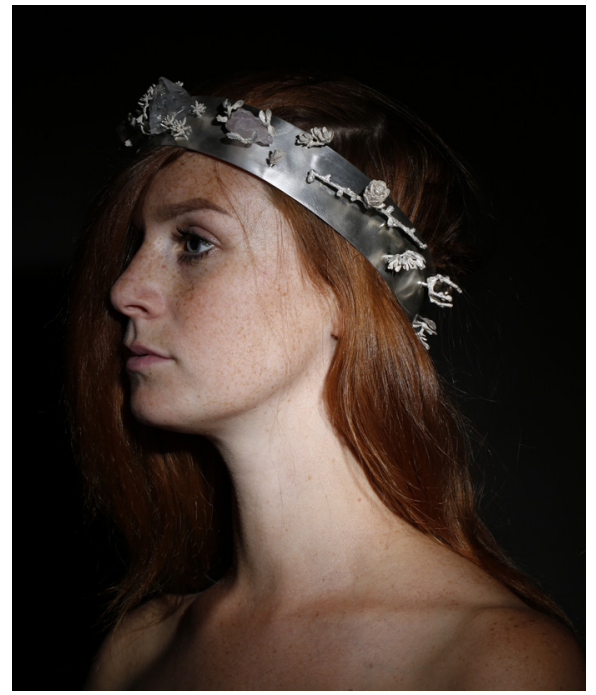

Obr. 18. Diadém z dílny Hanuše Lamra. Modelkou je Kateřina Kočí, produkční výstavy. Foto: O. Tlapáková. 


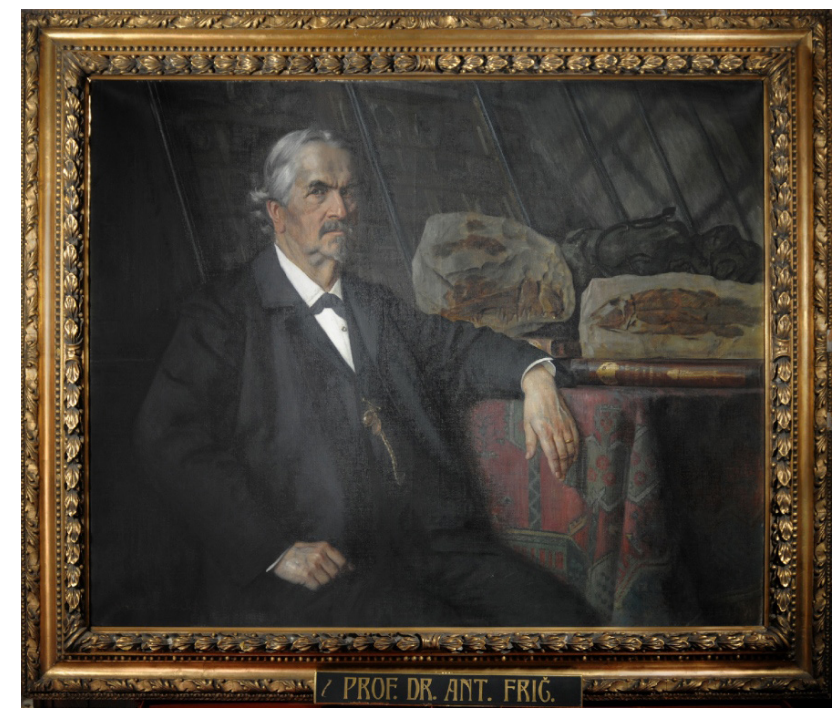

Obr. 19. Portrét Antonína Friče (1832-1913) namaloval roku 1902 Augustin Vlček (1865-1934). Vyobrazeny jsou na něm i dvě zkameněliny: čelist ryby rodu Xiphactinus a celá ryba rodu Macropoma. Na obraze je dále zachycena rekonstrukce nýřanských krytolebců a Fričova nejslavnější kniha. V pozadí stojí nové vitríny expozice paleontologie. Foto: NM.

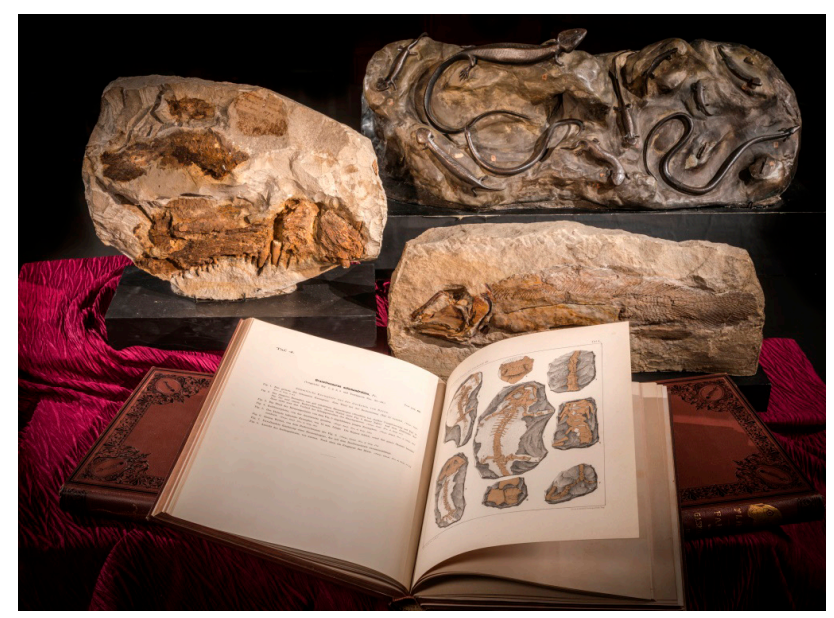

Obr. 20. Exponáty zachycené na obraze výše. Zleva: horní čelist s obrovskými zuby (podobné nálezy z Anglie byly dříve připisovány velkým mořským plazům, později se ukázalo, že patří 4-5 m dlouhé rybě Xiphactinus); nejstarší dochovaná česká trojrozměrná paleontologická rekonstrukce, která představuje skupinu starobylých ocasatých obojživelníků, kteří žili před více než 300 miliony let v prvohorních tropických jezerech (lokalita Nýřany u PIzně); druhohorní lalokoploutvá ryba Macropoma speciosum (nacházely se v opukových lomech mezi Mělníkem a Litoměřicemi); kniha Fauna der Gaskohle und der Kalksteine der Permformation Böhmens. Foto. M. Frouz. 


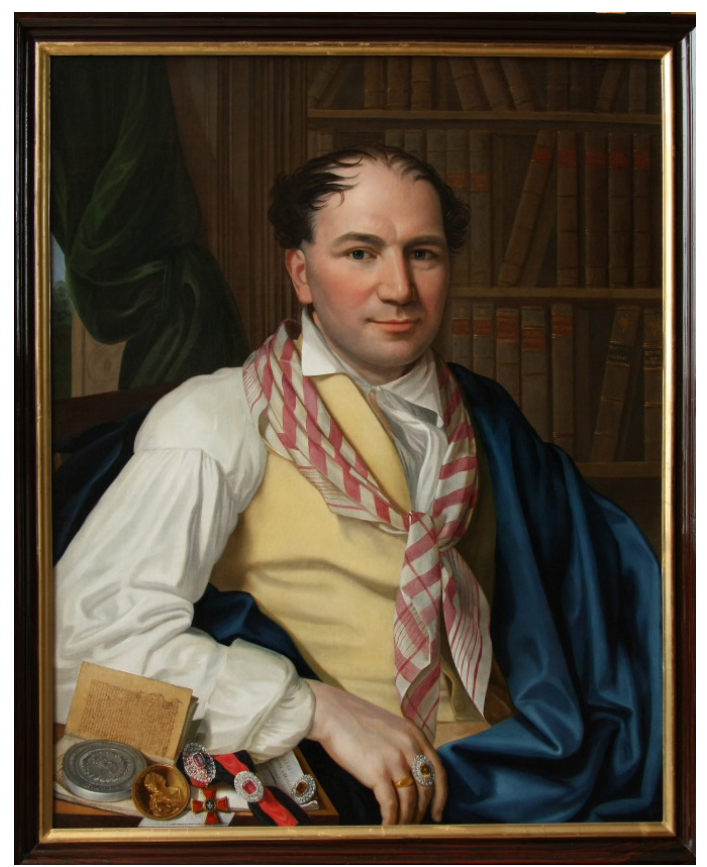

Obr. 21. Václav Hanka (1791-1861), náš první profesionální muzejník. Bohužel se sbírkami zacházel poněkud svévolně. Máme mnoho dokladů, že je různě „restauroval“, doplňoval a „vylepšoval“. Antonínu Machkovi dal dokonce čtyřikrát doplňit svůj portrét, původně namalovaný v roce 1821, a to pokaždé, když získal nějaké nové vyznamenání. Foto: 0 . Trmalová. hrabě Klebelsberg s podporou svých prríbuzných Františka Josefa hraběte Šternberka-Manderscheida a Kašpara Marii hraběte Šternberka. Oba Šternberkové zastupují ve výstavě skupinu zakladatelů, oba ale byli i významnými donátory muzejních sbírek.

Úplně prvním zaměstnancem muzea byl, kvůli sporu o pravost rukopisů neslavně proslulý, Václav Hanka (obr. 21). Pracoval jako správce knihovny, ale také archivu, prehistorických, historických a numismatických sbírek. Zaměstnancem muzea byl i slavný historik František Palacký. To jemu vděčíme za promyšlený program budování sbírek a novou koncepci muzea jako „obrazu vlasti“.

U zrodu paleontologických sbírek stál Joachim Barrande, který odkázal instituci statisíce zkamenělin i svou knihovnu. Když ho totiž Kašpar hrabě Šternberk jako stavebního inženýra požádal o prozkoumání možnosti postavit koněspřežku mezi Prahou a Plzní, objevil paleontologické bohatství oblasti, která nyní nese jeho jméno - Barrandien. Antonín Frič (obr. 19), ředitel zoologického a paleontologického oddělení, zoolog a paleontolog, který působil v muzeu více než šedesát let, je považován za tvůrce moderního prrírodovědného muzea. Ve své době se ve způsobech prezentace muzejních sbírek inspiroval především v Londýně a byl kritikem právě dostavěné nové budovy pro muzeum na Václavském náměstí.

Jediná žena mezi zakladateli Josefa Náprstková (obr. 16), manželka známého pražského mecenáše a zakladatele Českého průmyslového muzea Vojty Náprstka, pokračovala po smrti manžela $v$ jeho díle a díky svým organizačním schopnostem a pracovitosti značně rozšírila muzeum a jeho sbírky. Bez ní by Náprstkovo muzeum nebylo nejvýznamnější českou institucí věnující se mimoevropským kulturám.

Kašpar Maria hrabě Šternberk, František Josef hrabě Šternberk-Manderscheid, Václav Hanka, František Palacký, Joachim Barrande, Antonín Frič, Josef Schulz a Josefa Náprstková byli hrdí na svůj podíl na vzniku sbírek Národního muzea, což dokazují i některé jejich portréty, kde se s darovanými artefakty nechali zvěčnit. Součástí sbírek jsou dodnes, jak se mohli návštěvníci přesvědčit. Například na portrétu Antonína Friče z roku 1902 vyobrazil malíř Augustin Vlček čelist ryby rodu Xiphactinus, zkamenělinu celé ryby rodu Macropoma, model nýřanských krytolebců, stejně jako Fričovu nejslavnější knihu. Všechny tyto artefakty jsou vystaveny spolu s obrazem (obr. 20).

Odkaz nejen těchto osobností z dějin Národního muzea je platný dodnes. Předchůdci současných kurátorů byli také vědci, popularizátoři svého oboru i pečliví správci muzejních sbírek. A dodnes promlouvají k současníkům prostřednictvím své práce. Spojení minulých muzejníků s těmi dnešními ve výstavě symbolizuje audioposlech, sestavený z citátů osobnos- 
tí z obrazů. Hlas jim propůjčili dnešní muzejní př́rodovědci, historikové, muzikologové a knihovníci. Francouze Joachima Barranda namluvil s krásným měkkým př́zvukem ředitel Českého muzea hudby, Ital Emanuele Gadaleta; prvního knihovníka Václava Hanku ředitel knihovny Martin Sekera; slavného historika Františka Palackého profesor historie a náměstek pro sbírkotvornou činnost Michal Stehlík; šlechtice a př́rodovědce Kašpara hraběte Šternberka, který dokonce založil jeden vědecký obor - paleobotaniku (v roce 2020 jsme oslavili 200. výročí), kurátor sbírky obratlovců a docent zoologie Petr Benda; hlas zoologovi a paleontologovi Antonínu Fričovi propůjčil paleoartista Jan Sovák (obr. 22); za Františka Josefa hraběte Šternberk-Manderscheida, který muzeu odkázal naprríklad cennou numismatickou sbírku, rodový archiv a asi 10000 knih, promluvil vedoucí oddělení rukopisů a starých tisků Richard Šípek; za architekta Josefa Schulze měl mluvit kunst-

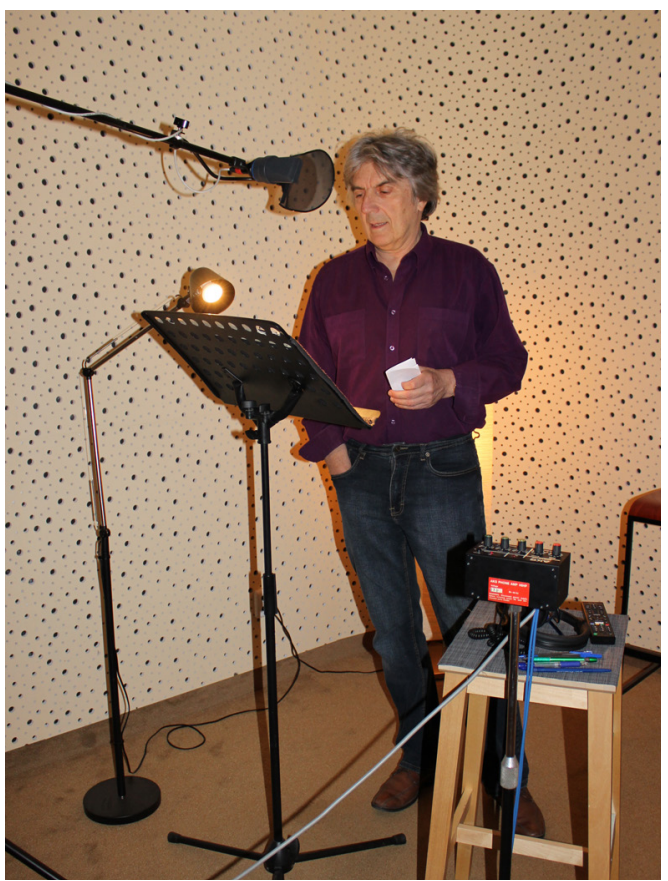

Obr. 22. Jan Sovák v nahrávacím studiu namlouvá text Antonína Friče. Foto: J. Dašková. historik Lubomír Sršeň (obr. 9), který nejen že je kurátorem jeho portrétu, ale dlouhodobě se zabývá i dějinami historické budovy, avšak z důvodu jeho indispozice se této úlohy ujal ředitel Historického muzea Marek Junek; Josefě Náprstkové nemohl zapůjčit svůj hlas nikdo jiný než současná ředitelka Náprstkova muzea a spoluautorka i kurátorka výstavy Eva Dittertová.

\section{Středověk a romantismus}

„Po hoře si zahrával chladný vítr a zanášel sem tam požloutlé listí. Mnohý list letěl dolů po hoře; bylo mu zde samotno, smutno, pusto v zřiceninách těchto; on letěl odsud' z chladné výše, aby zemřel dole mezi kvítím polním, bliže srdci lidskému; tak sestupují králové v stáří šedém s trünů zlatoskvoucích, aby sotva navrácení životu zemřeli v náručí lásky mezi lidem svým." (Karel Hynek Mácha: Večer na Bezdězu, Obrazy ze života mého)

V 19. století se umělci i vědci vraceli ke středověku, aby opěvovali jeho domnělou i skutečnou heroičnost a drsnou romantiku. Během národního obrození vedlo hledání kořenů českého národa, ve spojení s touhou po upevnění obrazu jazykově české literární tvorby, k vytváření falz středověkých rukopisů, která jsou vystavena vedle originálních středověkých pergamenových listin, bohatě iluminovaných rukopisů a původních středověkých artefaktů často vysoké umělecké hodnoty.

Karlova univerzita byla založena 7. dubna 1348 a 30. července 1366 ji Karel IV. hmotně zajistil vytvořením koleje pro dvanáct mistrů na Starém Městě pražském. Dokladem toho je vystavená zakládací listina koleje Karolina. Z doby Karla IV. pochází rovněž módní špičatý střevíc, patřící mezi archeologické nálezy z kláštera benediktinů Na Slovanech. Nízká uzavřená bota s páskem přes nárt odpovídá dobové módě a svým kvalitním zpracováním odráží vysokou úroveň ševcovského řemesla v Praze, kde byli údajně ševci nejčetnějšími řemeslníky. V neposlední řadě náleží do doby Karla IV. vzácně dochovaná vitráž s postavou sv. Ondřeje, pocházející z kostela sv. Jakuba Většího v Žebnici u Plzně, odkud byla vyjmuta roku 1911. 


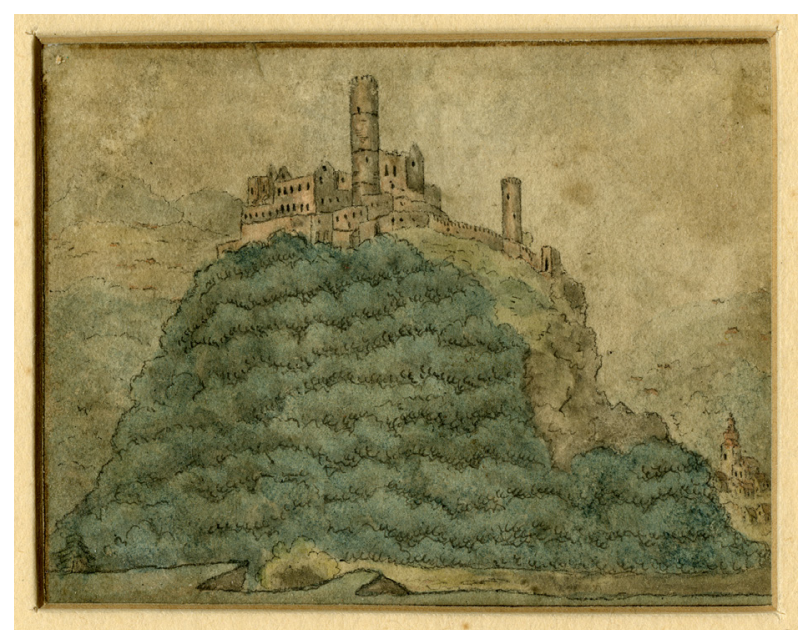

Obr. 23. Máchova kresba hradu Bezděz (1832). Hrady Mácha kreslil většinou z dálky a používal dalekohled. Kresba je součástí Sbírky Bohuslava Duška (1886-1957), prokuristy Živnostenské banky. Muzeu ji věnovala na základě jeho přání vdova Hermína Dušková v roce 1977. Foto: NM.
Kostel byl vystavěn v první polovině 14. století a šest zdejších původních vitrážových oken tvoří nejstarší dochovaný soubor vitráží v Čechách.

Z doby vlády Karlova syna Václava IV. je vystaven pečetní prsten Jíry z Roztok, oblíbeného člena Václavovy družiny. Jíra z Roztok byl členem královské rady, nejvyšším královským lovčím, vrchním představitelem královské hutě a purkrabím na Křivoklátě. Václav IV. jej roku 1380 povýšil do šlechtického stavu, přičemž mu udělil erb s vránou. Právě tento erb zdobí vzácně dochovaný prsten ze zlata vysoké ryzosti nesoucí Jírovo jméno.

Jistebnický kancionál,

nejvýznamnější hudební rukopis českého pozdního středověku, obsahuje nejstarší dochované česky psané liturgické zpěvy, duchovní a válečné písně. Nejznámější z kancionálu, vzniklého kolem roku 1450, je píseň Ktož sú Boží bojovníci. V žádné jiné zemi, kde se sloužilo v latinském ritu, se nedochoval tak raný kancionál v národním jazyce. Díky své mimořádné hodnotě, kterou rozpoznali historici Martin Kolář a František Palacký, byl kancionál objevený roku 1872 zařazen do sbírek Národního muzea.

K nejtypičtějším symbolům středověku, k nimž se romantismus vracel, patřily hrady a zř́íceniny poznamenané zubem času natolik, že jejich rozvaliny často splývaly s divokou př́rodou, jež je obklopovala. Karel Hynek Mácha, patřící bezesporu k největším českým romantickým básníkům, se rád toulával českou krajinou a své dojmy zachycoval i štětcem. Kolorovaná kresba hradu Bezděz z roku 1833 (obr. 23) je součástí cyklu 115 kreseb a akvarelů „hradů spatřených", které Mácha během cest vytvořil.

Odlišný pohled na fascinaci středověkem nabízí Píseň pod Vyšehradem, falzum napodobující středověkou milostnou lyriku, které je prvním rukopisem ze souboru falz nalezených v průběhu národního obrození. Josef Linda ještě jako student „objevil“ tento pergamen v roce 1816 v deskách knihy, kterou používal jako podložku. Písmena, která byla hůře čitelná, obtáhl černidlem. Lindův spolubydlící Václav Hanka (obr. 21), který později pracoval jako první knihovník Knihovny Národního muzea, tuto píseň několikrát vydal. Sám Václav Hanka později „nalezl“ známější falzum Rukopis královédvorský. Píseň psaná ve staročeštině měla napodobovat milostnou lyriku 13. století.

\section{Hudba a melodie}

„Vhudbě život Čechů.“ (Bedřich Smetana při slavnosti kladení základního kamene Národního divadla, 16. května 1868)

Hudba provází člověka odjakživa, hudbou lze vyjádřit radost i smutek. Některá hudební díla umírají hned po svém zrození, z jiných se stávají symboly. Hudba byla stejně jako instituce Národního muzea v 19. století jedním z motivů uvědomění českého národa.

Vzhledem $\mathrm{k}$ povaze vystavovaných předmětů jsme v tomto případě udělaly výjimku a téměř všechny předměty z Českého muzea hudby jsme soustředily na jedno místo. Po obvodu 
výstavního prostoru jsou rozmístěny autografy a partitury význačných hudebních skladatelů. Najdete tu skutečné poklady - symfonii $Z$ nového světa od Antonína Dvořáka i jeho neméně slavnou Rusalku (obr. 24) a Adagio für Mandoline und Cembalo od Ludwiga van Beethovena. Beethoven ho složil během svého tříměsíčního pražského pobytu pro zpěvačku a hráčku na cembalo, komtesu Josefinu Clary-Aldringen. $\mathrm{V}$ dalších vitrínách je $\mathrm{k}$ vidění například autograf symfonie Asrael, kterou Josef Suk napsal jako odezvu na smrt svého učitele a tchána Antonína Dvořáka, nebo temperamentním a špatně čitelným rukopisem zapsaná Říkadla Leoše Janáčka. Obdivovat je zde možné takové národní poklady, jako např́klad píseň Kde domov můj, či dílo Bedřicha Smetany, které zastupují hned tři kusy: partitura Vltavy z cyklu Má Vlast, Prodaná nevěsta, jejíž premiéru nastudoval a 30. května 1866 řídil sám autor, a partitura opery Libuše, kterou Bedřich Smetana považoval za své nejdokonalejší dílo. Tu dokončil již v roce 1872, původně byla určena ke korunovaci císaře Františka Josefa I. českým králem, ale zazněla poprvé až o mnoho let později, a to 11. června 1881 při otevření Národního divadla. Smetana ji již neslyšel. Všech 12 vystavovaných děl je doplněno i o poslechovou část - před každou vitrínou jsou umístěna sluchátka, ve kterých se rozeznívá každé z vystavovaných děl.

Notové záznamy doplňují další předměty: do dnešních dnů se např́íklad dochovala divadelní cedule k představení Mozartovy opery Don Giovanni, které se odehrálo 12. záŕí 1788, pokladnička z roku 1881, do které byly vybírány příspěvky na obnovu požárem zničeného Národního divadla, nebo závěs z královské, později prezidentské lóže. Ten byl vyroben vídeňskou firmou Carl Giani, zdobí ho znak Českého království a vyvěšoval se v průběhu návštěvy hlavy státu. Požár kupodivu přežil a sloužil dál během návštěv Františka Josefa I., Tomáše Garrigua Masaryka, Edvarda Beneše a naposledy Emila Háchy.

Z hudebních nástrojů kurátoři vybrali slavné stradivárky z roku 1729, na které hrál i Josef Suk ml., pumort tenorový - dřevěný dechový nástroj z 16 . století patřící tzv. rožmberské kapele (působila v jižních Čechách za vlády Rožmberků) nebo hoboj ze zimostrázového dřeva, na který hrál Bedřich Smetana. Tento hoboj vyrobil ve Vídni Wolfgang Küss, jehož nástroje byly tak věhlasné, že se již za jeho života padělaly. Na závěr se podívejme na nádhernou pedálovou harfu. Okolo roku 1900 ji vyrobil Alois Červenka, vystudovaný učitel, který ale se svým

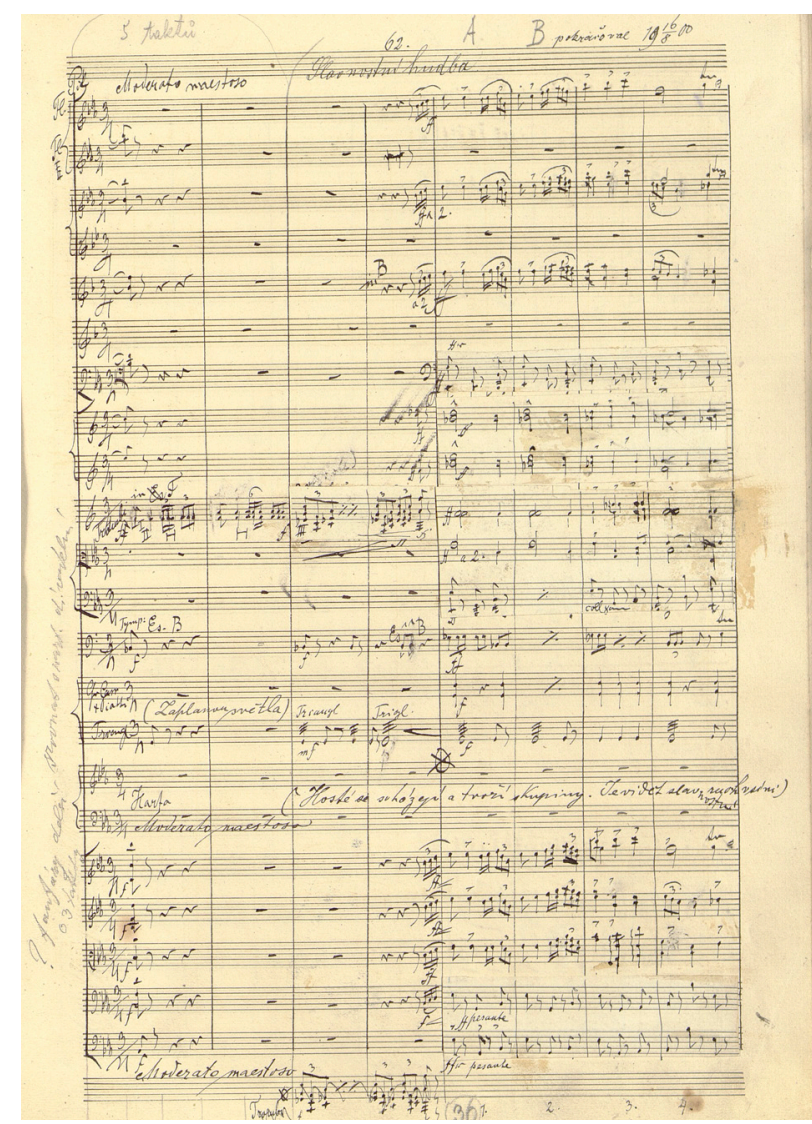

Obr. 24. Autograf opery Rusalka Antonína Dvořáka (18411904). Operu složil Dvořák na sklonku života v roce 1900 a je vyvrcholením jeho skladatelské kariéry. Foto: NM. 
povoláním nebyl spokojený, a tak se raději vyučil varhanářství. Varhany stavěl a opravoval v Domažlicích. Za svou harfu vytvořenou v gotickém slohu získal dokonce na zemské jubilejní výstavě stř́ibrnou medaili.

\section{Kámen a papír}

„Chceš-li slovo uchovat roky, svěr ho papíru, chceš-li slovo uchovat staletí, vytesej ho do kamene, chceš-li slovo uchovat na věky, naplň ho skutky." (anonym)

Stejně jako zkameněliny, starověké tesané nápisy i kniha nese poselství minulosti. Pamět' ukrytá v kameni i papíru nám pomáhá vyprávět dávnou i blízkou historii nás i naší země.

Tomuto tématu s trochou nadsázky přezdíváme „výstavka paleontologického oddělení", přestože ústředním exponátem je umělecká knižní vazba. Tu podle návrhu Zdeňka Buriana vytvořil knihař Josef Hodek. Na knihu Divy prasvěta Josefa Augusty s ilustracemi Zdeňka Buriana použil sloní kůži.

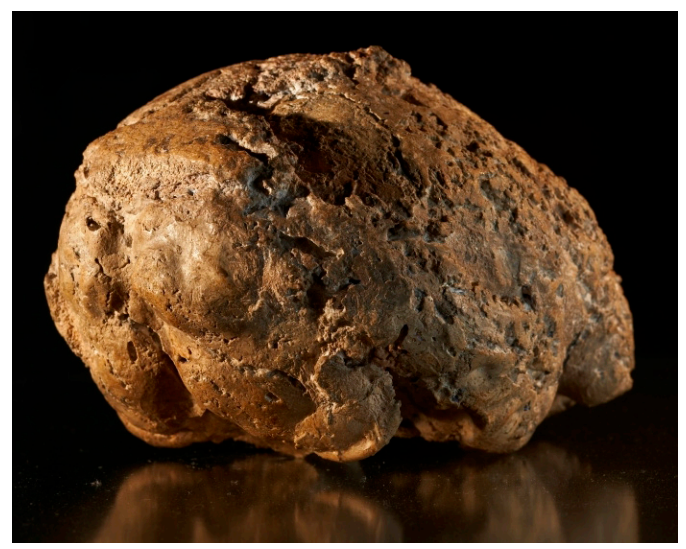

Knihu obklopují především zkameněliny, například nejslavnější česká dinosauří kost, kterou vystavujeme vůbec poprvé (obr. 26) a nese jména obou výše uvedených pánů - Burianosaurus augustai, nejdéle známá rostlinná zkamenělina, tzv. jáchymovské dřevo (nalezeno horníky 7. 2. 1557) i jediný kosterní soubor křídového ptakoještěra z Čech (Cretornis hlavaci). Pavouk na listu prvohorní rostliny je svědkem dávné katastrofy (výbuchu sopky), ke které došlo před 309 miliony let. Jeho tělo bylo zasypáno sopečným popelem podobně jako mnohem později Pompeje.

Obr. 25. Výlitek mozkovny nejstarší formy neandertálského člověka, který žil ve střední Evropě v poslední době meziledové, patří k ojedinělým nálezům pozůstatků předchůdců člověka. Byl nalezen $v$ roce 1926 náhodným sběrem $v$ travertinové kupě v lokalitě Gánovce nedaleko Popradu na Slovensku. Foto: M. Frouz.

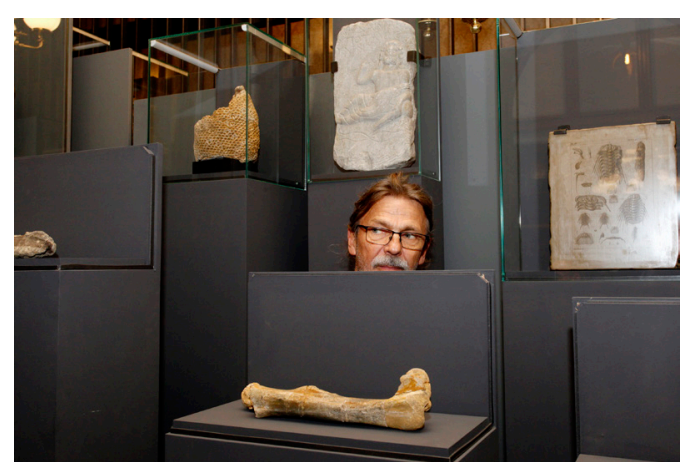

Obr. 26. Luděk Novotný (LN-design, s. r. o.) během instalace dinosauří kosti. Ta byla veřejnosti představena poprvé od svého objevení Michalem Moučkou v roce 2003. Foto: J. Vaněk. $\mathrm{V}$ záhadném trilobitovi $\mathrm{s}$ názvem Harpides grimmi vědci teprve nedávno objevili dochovaný otisk zažívací trubice a ozubenou horní čelist druhohorního mořského plaza našel úplnou náhodou Jan Hurych, když přesazoval třešeň na zahradě svých rodičů. Nejméně nápadným předmětem je jeden z nejvzácnějších, které přírodovědecké muzeum uchovává, výlitek mozkovny neandertálského člověka (obr. 25). Je jediný na světě a pochází ze slovenské lokality Gánovce a za pouhých 100 korun jej od kamenického mistra Kalmana Kokiho zakoupil všestranný badatel Jaroslav Petrbok. Tehdy se domníval, že se jedná o zkamenělý mozek mamuta či slona.

V kontextu se zkamenělinami jsou vystaveny historické artefakty. Na votivní mramorové stéle $\mathrm{z}$ oblasti Malé Asie ze 4.-5. století jsou vyobrazeny dvě ryby a nad nimi na boku ležící říč- 
ní bůh Potamos. V jedné ruce drží větvičku a z druhé mu pramení voda. Z litografické desky byla tištěna jedna z tabulí do vědeckého díla Joachima Barranda Système Silurien, světově nejrozsáhlejšího vědeckého díla vytvořeného jediným autorem. Podobných kamenných matric muselo být pro ilustrování Barrandova díla, věnovaného živočichům českých prvohor, vytvořeno 1160 !

\section{Zlato a pozlátko}

„Zlatý věk přijde ve chvíli, kdy lidé zapomenou na zlato." (G. K. Chesterton)

Symbolika zlata není dána pouze cenou materiálu ani jen jeho krásnou barvou. Zlato je určené vítězům, vládcům a št’astlivcům. Zlatá rybka měla splnit tři přání, vítěz získá zlatou medaili, královské insignie jsou ze zlata. Téma představuje zlato $v$ jeho hlubších významech, symbolice a souvislostech.

Luxusní zlatá róba české herečky Adiny Mandlové připomíná její kariéru hvězdy stříbrného plátna, zlatý trikot české krasobruslařky Áji Vrzáňové, ve kterém vyhrála mistrovství světa v Paříži v roce 1949, pak vrchol její hvězdné kariéry. Obě byly královnami ve svém oboru. Vládce světa zvířat symbolizuje mezi nimi umístěná vycpanina vzácné malé opičky - lvíčka zlatého. Opička žila v olomoucké zoologické zahradě a jmenovala se Zrzek (obr. 27). Mistrovi ze světa hudby Antonínu Dvořákovi patřil zlatý Řád železné koruny III. třídy a čestný odznak pro vědy a umění, které mu udělil císař František Josef I. Zlatý stodukát Ferdinanda III. z roku 1629 se řadí k nejcennějším exponátům výstavy. Na celém světě se jich dochovalo pouhých pět, z toho dva ve sbírce Národního muzea. 0 výjimečnosti této mince svědčí i skutečnost, že na světových numizmatických aukcích se tento vzácný peníz nedražil více než sto let. Zlatý prsten s diamantem herce Eduarda Vojana ukazuje, jak pomíjivá a vrtkavá je sláva, nejen ta herecká. Že zlato může symbolizovat i nenaplněné ambice, naznačuje největší diamantový šperk v České republice, který nechal pro svoji ženu Naděždu vyrobit z lásky politik Karel Kramár. Náhrdelník je osazen 148 diamanty a tvaroslovím odkazuje k diamantovým hvězdám rakouské císařovny Alžběty, zvané Sissi. Karel Kramár ho nechal zhotovit postupně v době, kdy snil o tom, že bude stát $\mathrm{v}$ čele země, což se mu poštěstilo jen na krátkou dobu coby prvnímu předsedovi vlády Československé republiky. Jeho žena Naděžda měla pak zřejmě stát po jeho boku ozdobena tímto náhrdelníkem podobně jako císařovna po boku císaře. Ale štěstěna jim tento okamžik nedopřála. Svoji přívětivější tvář ukázala atletu Ludvíku Daňkovi. Svou zlatou medaili získal na olympiádě $v$ Mnichově v roce 1972 získal navzdory celoživotním zdravotním potížím po vážné autonehodě.

Vedle všech těchto předmětů, které formovala ruka člověka a které symbolizují mimořádné po- 
stavení svých majitelů, téměř zaniká unikátní velký kus surového zlata, tzv. křepické zlato. Ve skutečnosti se ale jedná o jeden z nejkrásnějších kusů zlata nalezených na našem území. Kousky v nálezu dosahují až $10 \mathrm{~cm}$, mají typickou trojúhelníkovou kresbu na povrchu a září stejně jako velkolepé šperky.

\section{Rituály blízké a vzdálené}

„My už pomalu neumíme někoho slavit. Za slavení obvykle považujeme nějaké dobré papu a pití, ale to není slavení. Naši předkové slavili tak, že měli muziku a tanec a sousedské povídání, kdy se nemluvilo o hnoji, ale o zážitcích a společenství vesnice. A také společně uznávali hodnoty. A když stáli před hodnotami nejvyššími, s úctou se klaněli. A úcta je slovo, které má i dnes budoucnost." (Jiří Reinsberg)

Rituály provázejí člověka napříč kulturami a věky od kolébky do hrobu a jejich podoby jsou stejně pestré jako dějiny lidské religiozity, jejímž jsou projevem. Často jsou s nimi spojeny mimořádné umělecké objekty, uchovávané stejně jako tradice rituálu po řadu generací.

Důležitou součást rodinného majetku a ženina věna tvořily kruhové spony zvané tabzimt (obr. 28). Dostávaly je ženy z etnika Kabylů v horských oblastech Alžírska od svých mužů po narození prvního syna. Do Náprstkova muzea tuto sponu věnoval spisovatel Julius Zeyer, který ji zakoupil na Světové výstavě v Pařízi roku 1889.

Obřad iniciace mladých dívek v severní oblasti dnešní Jihoafrické republiky dokládá skalní rytina, kterou dovezl slavný cestovalel Emil Holub. Obřad završený rituální očistou

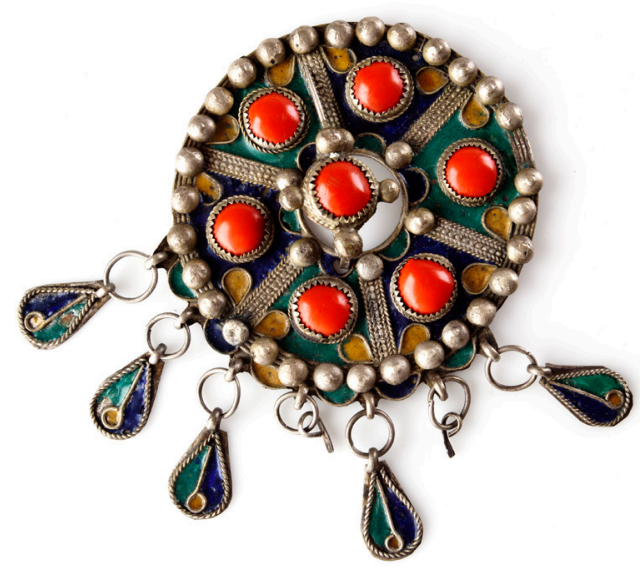

Obr. 28. Kabylský šperk k narození syna je zhotoven ze stříbra a zdobí ho smalt a červené korály. Foto: J. Vaněk. mladých př́slušníků aristokracie národa Nutků v oblasti Vancouveru v Kanadě připomíná vlčí nástavcová maska.

Velmi různorodé jsou rituály doprovázející spojení muže a ženy. Červenofigurový lutroforos, štíhlá vysoká váza z 5 . století př. n. l., sloužil $\mathrm{k}$ přenášení vody $\mathrm{z}$ posvátného pramene. $Z$ vody pak byla připravena koupel pro nevěstu, ale možná i ženicha před svatbou. Tato symbolická očista měla rovněž zajistit plodnost a sloužila také k omývání mrtvých. Pokud někdo zemřel svobodný, byl mu lutroforos postaven na hrob, protože se zasnoubil s podsvětím. Tento lutroforos zdobí stejně jako většinu ostatních svatební a pohřební výjevy. Zcela odlišný charakter má dal-

ší keramická nádoba z Peru (100-800 n. l.) a zobrazující pár při rituálním sexu (obr. 29). Keramika mochické kultury se vyznačuje naturalisticky ztvárněnými náměty z každodenního života, k nimž patří zvírata, šamani i bojovníci. Nádoby s erotickými motivy pocházejí z nálezů v hrobech elit. K nejpropracovanějším pohřebním rituálům patřily nepochybně ty egyptské. Slavná „pražská rakev“ byla určena pro pohřeb muže z doby 22. dynastie v Údolí králů. Z neméně slavného archeologického naleziště syrské Palmýry byla dovezena náhrobní stéla, na které je vyobrazena žena s novorozencem.

K časově i místně bližším patří rituály křestanské, zastoupené svatebním pohárem vyrobeným v Muranu u Benátek kolem roku 1500, z nějž pili oba manželé po svatebním slibu, aby symbolicky potvrdili svůj svazek. Křest a večeři Páně jako nejvýznamnější svátosti, a zároveň jediné svátosti uznávané protestantskými církvemi, zastupují následující dva 
předměty. Prvním je křestní komplet používaný sto let. Křest jako první veřejné přijetí novorozence ve společnosti byl neodmyslitelně spojen s pečlivým výběrem slavnostního oděvu, který se často dědil po mnoho generací. Křestní komplet kabátku a čepičky dala zhotovit Marie Breüerová v roce 1835 a postupně v něm bylo pokřtěno 21 dětí $\mathrm{z}$ její rodiny. Druhým předmětem, tentokrát souvisejícím se slavením večeře Páně, je stř́ibrný, částečně pozlacený kalich z kolínského knížecího hrobu, kde byl nalezen ve společném hrobu muže a ženy. Protože byl hrob dříve považován za místo posledního odpočinku husitského kněze Prokopa Holého, byl kalich následně upraven a používán při bohoslužbě jako nádoba na Krev Páně.

Rituály neodmyslitelně doprovázejí člověka i na jeho poslední cestě. Pro pohřeb jihočeského šlechtice Petra Voka z Rožmberka (1539-1611) byl zhotoven oválný, dřevem podložený pohřební štít potažený látkou protkávanou stříbrnými nitěmi. Střed zdobí plastická aplikace z látek - reliéfně provedený Vokův znak umístěný mezi dvěma medvědy - štítonoši. Štít byl součástí výzdoby objednané pro jeho pohřeb, který se konal 30. ledna 1612 v bývalém klášterním kostele ve Vyšším Brodě. Tam zůstal štít zavěšen až do roku 1843, kdy jej tehdejší opat cisterciáckého kláštera Valentin Schopper daroval Národnímu muzeu v Praze.

\section{Fauna a flóra}

„Jestliže nám někdy př́roda připadá nádherná, tak tahle přidaná hodnota nemůže být dílem př́rody, nýbrž umělce." (G. K. Chesterton)

Př́roda je věčným zdrojem inpirace a krásy. Od nepaměti naši předci nacházeli ve světě zvířat a rostlin materiál i vzory pro běžné i umělecké předměty.

Některé předměty prezentují dokonalé souznění uměleckého artefaktu se světem př́rody. Soška posvátného ibise patří mezi TOP 10 Národního muzea. Na první pohled sice malá, ale výjimečně řemeslně zpracovaná soška vyrobená z egyptského alabastru, bronzu a dřeva představuje posvátné zvíře staroegyptského boha Thovta a je více než 2500 let stará. Obdobné sošky lze nalézt i v jiných světových muzeích, ale tato vyniká krásou svého provedení. Stejně starý jako samotné Národní muzeum je pomologický kabinet Johanna Volkmara Sicklera z roku 1818. Jedná se celkem o 298 modelů ovoce. Detailní modely dokonale vystihují barvu a povrchové struktury předlohy včetně drobných vad a nedokonalostí a podávají důležité svědectví o dříve oblíbených odrůdách, ze kterých dnes již velká část ani neexistuje nebo jsou na okraji zájmu. Model chobotničky ze skla (obr. 30) je věrnou skleněnou imitací chobotnice pižmové a vrcholnou ukázkou umělecko-technického ztvárnění živé přírodniny v model. Existuje pouze jediný originál. Tuto skleněnou chobotnici vyrobili Leopold Blaschka a Rudolf Blaschka v Drážd’anech a v roce 1884 ji Leopold daroval Národnímu muzeu.

Na výšivce ústředního exponátu, tzv. koutnice, z 2. poloviny 18. století se snoubí svět fauny a flóry - motiv sedícího ptáka na keři. Koutní plachta (obr. 31) je rozměrná interi- 
érová textilie, která sloužila jako závěs chránící rodičku po dobu šestinedělí. I proto byl oblíbeným motivem výšivky na těchto textiliích strom života. Ulita mořského plže zavinutce, ryba na kování a motivy germánského zvěrného kruhu na sponách se objevují mezi predměty nalezenými v ženském kostrovém hrobě z 6. století ve Světci u Bíliny. Florální vzor svlačce zdobí flétnovou vázu umělce Makuzua Kózana, tvořícího pro japonského císaře $v$ době dynastie Meidži. Stylizované prořezávané květiny a rostliny krášlí rám indického dřevěného okna, které sloužilo k průhledu z ženské části domu do vnitřního dvora. Brož s realisticky ztvárněnými motivy klasů a listů z českých granátů je součástí kolekce granátových šperků Národního muzea, která je i ve světovém měřítku unikátní. Brož lze datovat mezi léta 1840 a 1860 . Právě v 19. století se český granát těšil největší oblibě, jelikož díky svému českému původu vhodně odrážel vlastenecké cítění.

Rostlinné a živočišné materiály jsou zastoupeny netradičně. Polštář z rafiových vláken zdobený plastickým geometrickým vzorem je jedním z nejstarších artefaktů dovezených z Afriky do Čech. Podle inventáře Pražského hradu byl součástí slavných rudolfínských sbírek již v roce 1607. Krátce střižená vlákna mladé rafiové palmy na dotek připomínají hebkou látku. Jedná se o tzv. bakubský samet, v jehož výrobě dodnes vyniká etnikum Bakubů z oblasti rovníkové Afriky. Tyto polštáře se používaly na klečení či sezení při ceremoniích u dvora konžského krále. Kabátek ze pštrosího peří ze 30. let 20. století představuje rovněž oděv luxusního charakteru. Vypráví ale i příběh 20. století. Patřil paní Bertě Engelmannové z bohaté židovské rodiny. Dvaaosmdesátiletá paní Berta byla zařazena do transportu, který odjel z Prahy do Terezína 9. července 1942. Zemřela za dva měsíce. V transportu bylo 962 lidí, válku jich přežilo jen 38. Kožich první dámy Hany Benešové je zhotoven z drobné, asi dvoukilové opičky chvostana bělolícího. Opičí kožešiny byly v době první republiky velmi oblíbené, avšak měly luxusní charakter, takže se používaly spíše na doplňky či lemy kožichů. K předmětům spojeným s výjimečnými osobnostmi patř́i i náušnice ve tvaru podlouhlé kapky z mořského korálu z pozůstalosti Boženy Němcové. Do obecného povědomí se dostaly i díky jejich zachycení na slavném portrétu od malíře Josefa Hellicha, později použitém na pětisetkorunové bankovce. Čestná taktovka ze slonoviny je spojena se skladatelem Bedřichem Smetanou. 


\section{Stříbro chladné i hřejivé}

„V oparu mlhy podzimní

tlumený luny svit.

Studí již zvlhlé hedvábí,

ona však nemění svůj šat.

Celou noc

rozeznívá stř́ibrné struny,

z obavy

shledat se sama v prázdném pokoji.“

(Wang Wej: Píseň podzimní noci)

Stř́íbro je kovem známým lidstvu již od starověku. Vzhledem k tomu, že se v zemské kủře vyskytuje jen vzácně a je dobře kujné, bylo vždy využíváno k ražbě mincí a výrobě šperků, ale v minulosti bylo používáno pro jeho dezinfekční účinky i jako lék. Díky chladnému lesku bývá přirovnáváno ke svitu měsíce. Jeho barva dala název řadě kožešin a promítla se i do luxusních společenských textilií, určených pro večerní příležitosti.

Ústřední a jediný „hřejivý“ exponát mezi všemi předměty ze stříbra tvoří společenský komplet ze stř́íbrnošedého hedvábného brokátu, doplněný o kožešinovou štólu z amerického norka, rovněž stříbrné barvy. Komplet byl ušit pravděpodobně $\mathrm{v}$ roce 1953 v módním závodě Eva, který vznikl zestátněním slavného prvorepublikového salonu Hany Podolské, pro paní Marii Velingerovou.

Předměty z chladného stř́ibra představují vzácné mince, umělecké předměty (obr. 10) a mimořádné šperky. Soubor šperků z hrobu „kněžny“ z první poloviny 10. století byl nalezen na raně středověkém hradišti ve Staré Kouřimi. Ikonickou částí souboru, známou i z učebnic dějepisu, je pár ozdob skrání s řetízkovými závěsky, zdobených plasticky vypracovaným zvírátkem (beránkem?), stojícím na podstavcích s vyobrazením hvězd kolem stromu života. Neméně výjimečná je románská čelenka zdobená figurami panovníků a bojovníků v arkádách (obr. 32). Byla nalezena nedaleko Českých Budějovic spolu s osmi záušnicemi při hloubení nového koryta pro tok Vltavy v roce 1937. Poslední šperk představuje filigránový pás, nošený ke kroji v Těšínském Slezsku, kde se stř́brné pásy s velkými filigránovými rozetami a bohatou řetízkovou výzdobou těšily velké oblibě (obr. 33).

Nejstarší česká mince, denár knížete Boleslava I., byla ražena v Praze před rokem 966. Donační dirham byl ražen ke slavnostním příležitostem, například

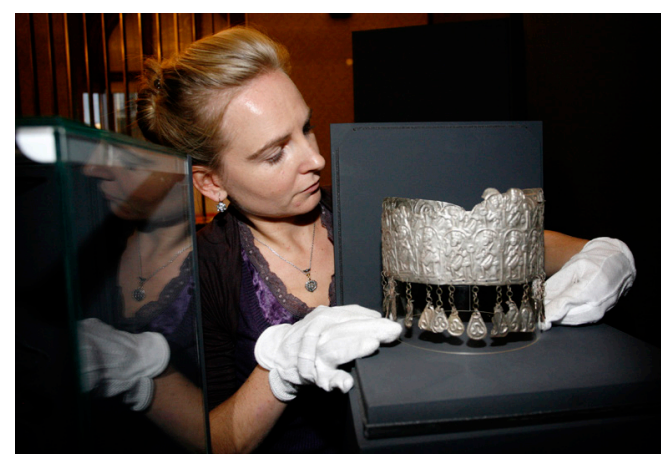

Obr. 32. Kurátorka sbírky zlatnických prací a spoluautorka výstavy Lucie Kodišová umistuje do vitríny vzácnou stríibrnou románskou čelenku. Čelenka byla nalezena nedaleko Českých Budějovic spolu s osmi záušnicemi při hloubení nového koryta pro tok Vltavy $\mathrm{v}$ roce 1937 . Foto: J. Vaněk.

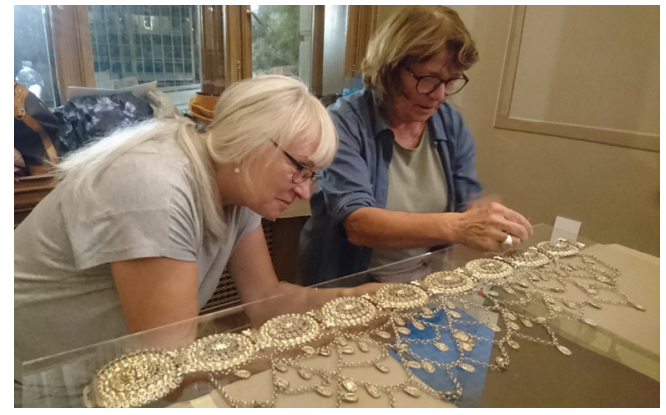

Obr. 33. Adjustace stříbrného filigránového pásu na plexi desku byla pro restaurátory a aranžérky llonu Přibilovou a Alenu Vrbovou precizní prací. Foto: J. Dašková. 


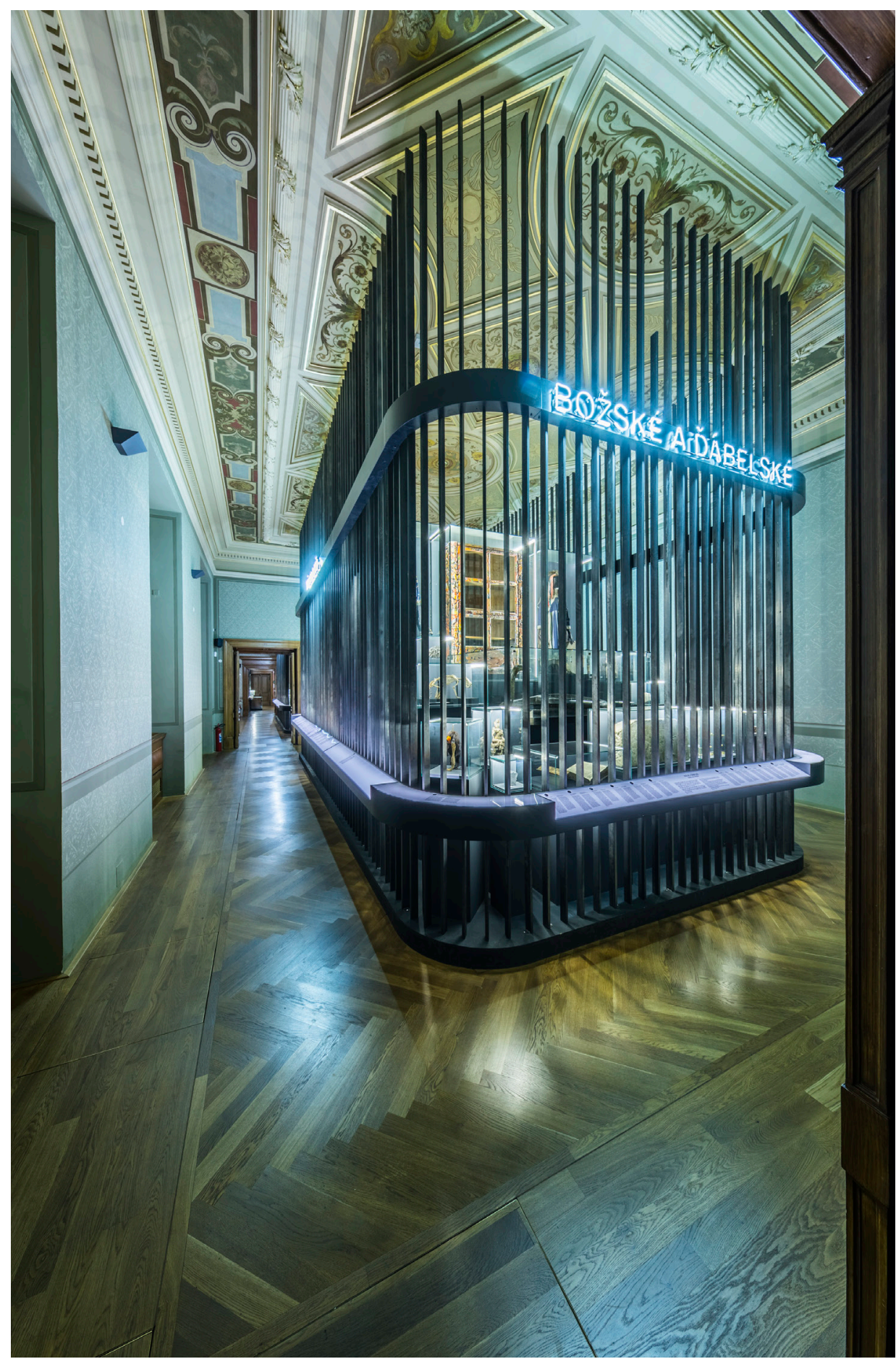

Obr. 34. Poslední (třetí) výstavní sál byl zakončen tématem Božské a dábelské. Vlevo je vidět průhled přes všechny tři sály. Foto: M. Frouz. 
korunovaci, svatbě či narození potomka, ve středověkém Íránu. Tento je připsán panovníkovi Alímu al-Muajjada, který vládl v letech 1364-1381. Jak může stříbro vypadat při nálezu, ukazuje unikátní srostlice částečně stočených drátů ryzího stříbra z norského Kongsbergu, kde se stř́bro těžilo od roku 1623.

\section{Božské a dábelské}

${ }^{1}$ Nejzchytralejší ze vší polní zvěře, kterou Hospodin Bůh učinil, byl had. Řekl ženě: „Jakže, Bůh vám zakázal jíst ze všech stromů v zahradě?"

${ }^{6}$ Žena viděla, že je to strom s plody dobrými k jídlu, lákavý pro oči, strom slibující vševědoucnost. Vzala tedy z jeho plodů a jedla, dala také svému muži, který byl s ní, a on též jedl.

${ }^{22}$ I řekl Hospodin Bůh: „Ted' je člověk jako jeden z nás, zná dobré i zlé. Nepřipustím, aby vztáhl ruku po stromu života, jedl a byl živ navěky."

${ }^{23}$ Proto jej Hospodin Bůh vyhnal ze zahrady v Edenu, aby obdělával zemi, z níž byl vzat. (Gen 3, 1, 6, 22-23)

Hřích a ctnost jsou ryze lidské vlastnosti. Člověk připsal dobro Bohu a zlo peklu a své představy promítl do umění i přírody. Co všechno může být označováno adjektivem božský nebo naopak dábelský, ukazuje výběr předmětů v tomto tématu.

Již od první čtvrtiny 20. století byla dominantou zoologické expozice 5,5 metru dlouhá samice anakondy velké a stala se i ústředním exponátem tohoto celku. Do muzea ji věnoval c. k. rakouský konzul v brazilském Paraná Jan Potůček. Byl to had, kdo podle Bible svedl člověka k hříchu, i proto zde stojí mezi Bohem a dáblem.

Nad anakondou se tyčí vysoké vitríny s předměty, které v sobě oba světy spojují. V jedné z nich je umístěno čínské dračí roucho. Zatímco v západní kultuře drak představuje straš-

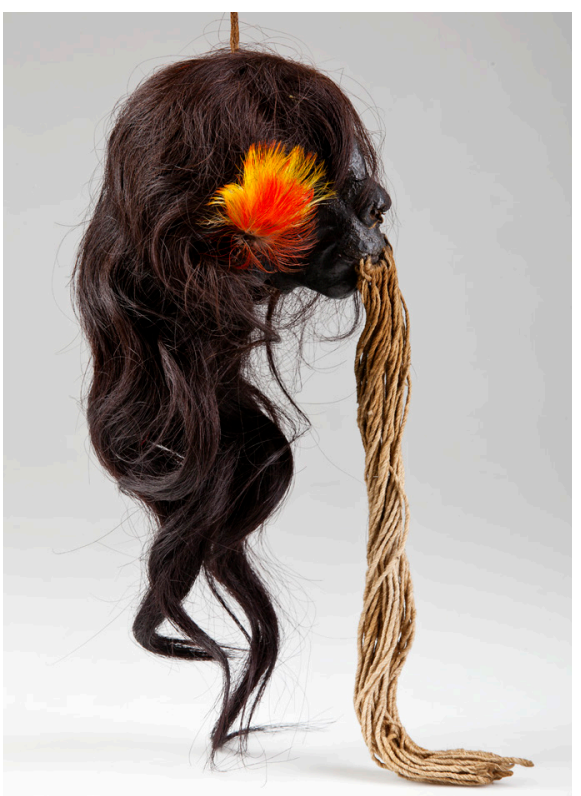

Obr. 35. Tsantsa. Tato hlava patřila náčelníkovi indiánského kmene Uitás (Uiquinů). Předmět pochází ze sbírky slavného českého cestovatele Enrique Stanko Vráze (1860-1932), jenž koncem 19. století pobýval mezi indiány v povodí Orinoka a Amazonky. Foto: J. Vaněk. livou prríšeru, ve východní kultuře je posvátným tvorem a zdobí polooficiální oděv úředníka - učence z doby dynastie Čching. Roucho zakoupil na Štědrý večer roku 1887 v Kantonu námořní komisař Václav Stejskal. Dalším oděvem je šamanský oděv ze severního Mongolska - peří na čapce je symbolem ptáků obývajících vyšší sféry, stuhy a textilní aplikace v podobě hadů odkazují k cestám šamana do podzemních světů. Kovové prívěsky, rolničky, řetízky a zrcátka symbolizují zbraně k ochraně před zlými silami. Pomocí bubnu s paličkou šaman vchází do transu a vstupuje na své „cesty“. Duše šamana totiž v transu cestuje do světů nepřístupných běžným lidem a setkává se tam s duchy, zemřelými a posvátnými zvíraty. A ve třetí velké vitríně stojí vyřezávaná knihovna Josefa Váchala. Zdobí ji démonické výjevy z pekla i Kristus na kříži. Josef Váchal ji vyrobil pro svou přítelkyni, grafičku Annu Mackovou.

Symboly zkázy mohou být meteority. Vystaveny jsou dva železné. Broumovský, který váží 17,23 kg, dopadl 14. května 1847 do domku cihláře, prorazil střechu a strop, roztříštil pelest postele, ve které spaly tři děti, ale zraněn nebyl naštěstí nikdo. Druhým je loketský, který patří mezi nejstarší známé meteority na světě. Nalezen byl pravděpodobně 


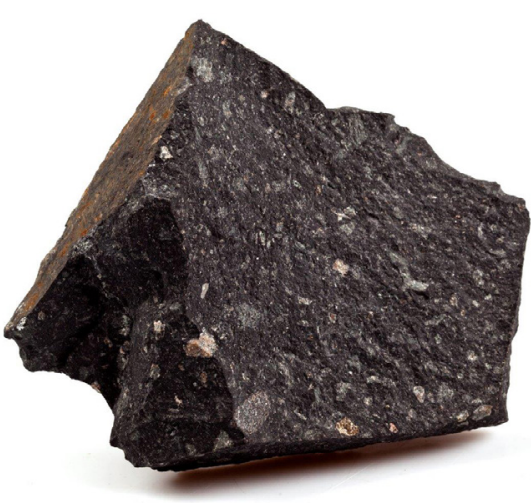

Obr. 36. Hornina suevit (impaktní brekcie) vznikla po dopadu obrovského asteroidu. Kráter, který během katastrofy vznikl, má v průměru 200 km a jde o jednu z největších známých impaktních struktur na Zemi. Foto: J. Vaněk. již v 15. století. Mezi lety 1811 a 1819 byl rozřezán na několik kusů. $Z$ nich 6,6 kg vážící kus daroval do Národního muzea profesor Univerzity Karlovy František Slavík. Vystavené meteority doplňuje hornina suevit, která vznikla při obrovské katastrofě před ca 1,8 miliardy let. Tehdy dopadl do oblasti dnešního Sudbury v Kanadě asteroid, jehož velikost mohla být 10-15 km. Nahromaděním úlomků hornin, které byly vyvrženy do několikasetkilometrových vzdáleností, vznikla hornina nazývaná suevit (obr. 36).

Ďábel má mnoho tváŕí i jmen. Satyr na antickém kyathu (keramická naběračka) je zpodobněn napůl jako kozel s rohy a napůl jako člověk. Loutky bizarně démonického i líbivějšího realisticky ztvárněného čerta navrhl Karel Svolinský pro firmu Antonína Münzberga. Vystavená kostra malého vačnatce patří dáblu medvědovitému, zvanému

též tasmánský čert či vačnatý dábel. Podmanit si sílu i duši protivníka pomáhala bojovníkům jívarských indiánů tzv. tsantsa - jeho hlava vypreparovaná speciální technikou v trofej (obr. 35).

„Božské“ z našeho území je v celku zastoupeno jak naší nejslavnější biblí, tzv. Melantriškou, tak i mimořádnou relikvií - mitrou sv. Eligia. Tento patron všech zlatníků žil ve Francii na přelomu 6. a 7. století. Relikvii do Čech dovezl císař Karel IV. Mitra byla nově restaurována a vystavena je tak unikátně mimo relikviář a zcela poprvé. Samotný gotický relikviář je vyroben z pozlaceného stř́́bra a destiček skla a křištálu.

Následníkem rakousko-uherského trůnu Františkem Ferdinandem d'Este byl dovezen jeden z nejvýznamnějších staroegyptských předmětů nacházejících se v českých veřejných sbírkách. Jde o reliéfní blok s vyobrazením krále Taharky (vládl v letech 690-664 př. n. l.). Z jiného koutu světa, z Mexika, pochází kamenná socha zobrazující bohyni úrody Chicomecoatl (v jazyce Aztéků „Sedm hadů“ nebo „Vzácná žena“). Z úcty k prezidentu Masarykovi ji Československu věnoval August Génin, podnikatel a spisovatel francouzsko-mexického původu.

\section{Válka a mír}

\section{„Být připraven na válku je nejúčinnější způsob, jak uchovat mír." (George Washington)}

Doklady mírových snah i krutých válek v naší minulosti se mohou někdy v příbězích sbírkových předmětů překvapivě potkávat.

Dalším z TOP 10 předmětů Národního muzea je stejnokroj prvního československého prezidenta Tomáše Garrigua Masaryka. Osobnost prvního československého prezidenta je výjimečná v mnoha ohledech a jeho životní styl, oděv i vztah k prezentaci vlastní osoby odpovídal celkové kompozici jeho prezidentského mandátu. Prostředkem k vyjádření této výjimečnosti byl Masarykovi i jeho oděv, konkrétně jeho typický sportovně laděný vycházkový „stejnokroj“. Ten se stal symbolem jeho zobrazení. Nejintenzivněji je vojenská inspirace patrná na čepici, která vycházela z tzv. „furážky“, používané československými legionáři v Rusku. Masaryk ji nosil na jejich pamět’ zdobenou bikolorou. Inspirace Masarykova oblíbeného oděvu vojenským stejnokrojem zřejmě souvisela s jeho úctou k legionářům, ale i sportovním a značně asketickým osobním životem prezidenta. Sám Masaryk byl totiž zapřisáhlý pacifista.

Děj románu Vojna a mír Lva Nikolajeviče Tolstého, jak už název napovídá, se odehrává v době válek, konkrétně napoleonských. Jeho první překlad do češtiny pořídil Vilém Mrštík, 


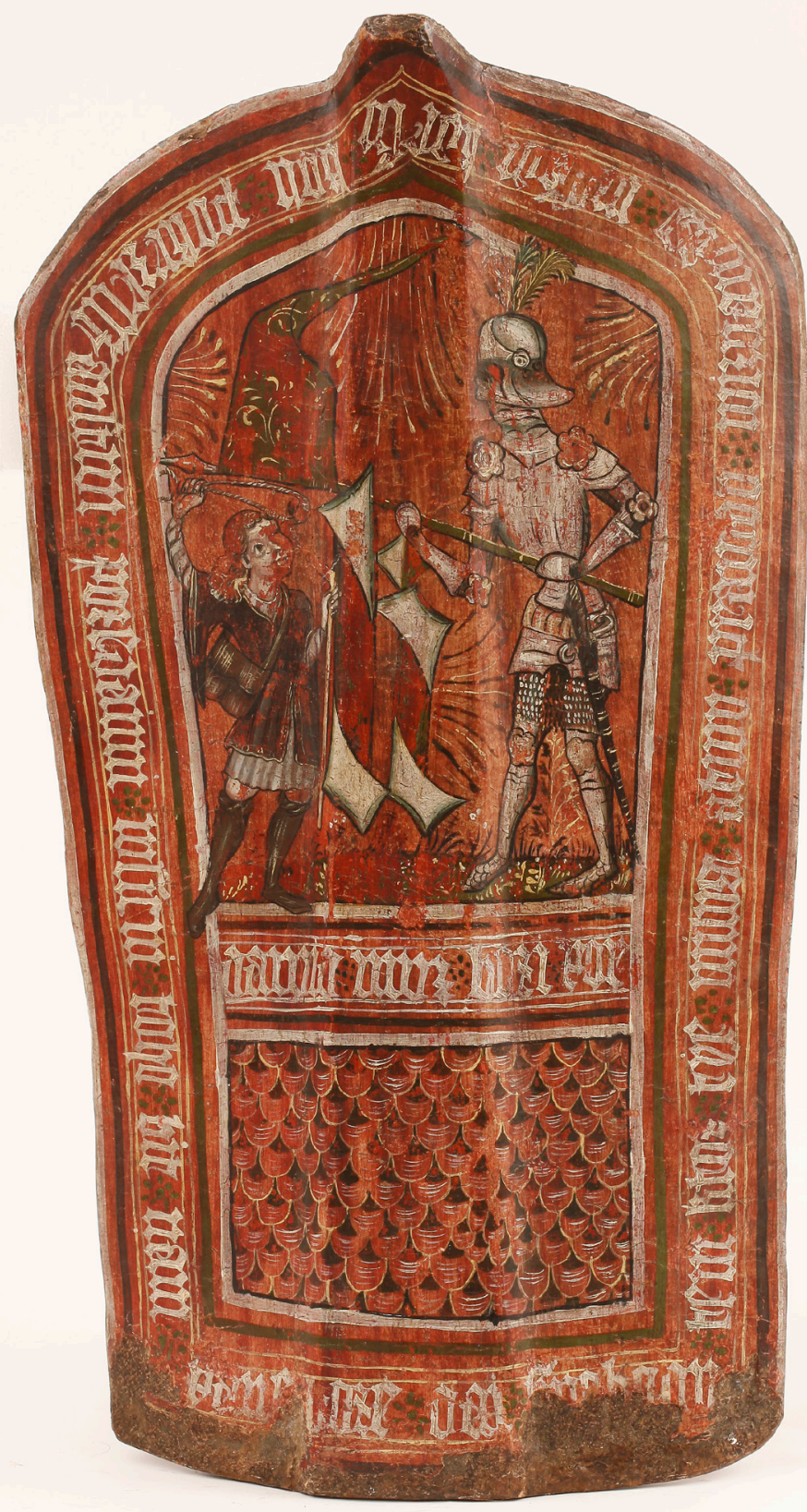

Obr. 37. Pavézy byly štíty chránící pěšáka před střelami z luků, kuší i prvních palných zbraní. Používali je jak křižáci, tak husité. Ze souboru asi 40 dochovaných pavéz českého původu není žádná přímo z doby husitských válek, všechny jsou o něco mladší. Zachovávají však tradiční podobu husitských pavéz. Poměrně malá (necelých $90 \mathrm{~cm}$ vysoká) pavéza s Davidem a Goliášem z doby kolem roku 1450 je díky své symbolické výzdobě nejznámější: chlapec David poráží pouhým prakem plně vyzbrojeného obra Goliáše. Dole začíná husitská píseň slovy: „Pane Bože, daj svobodu těm, ktož tě milují..." Foto: A. Kumstátová. 


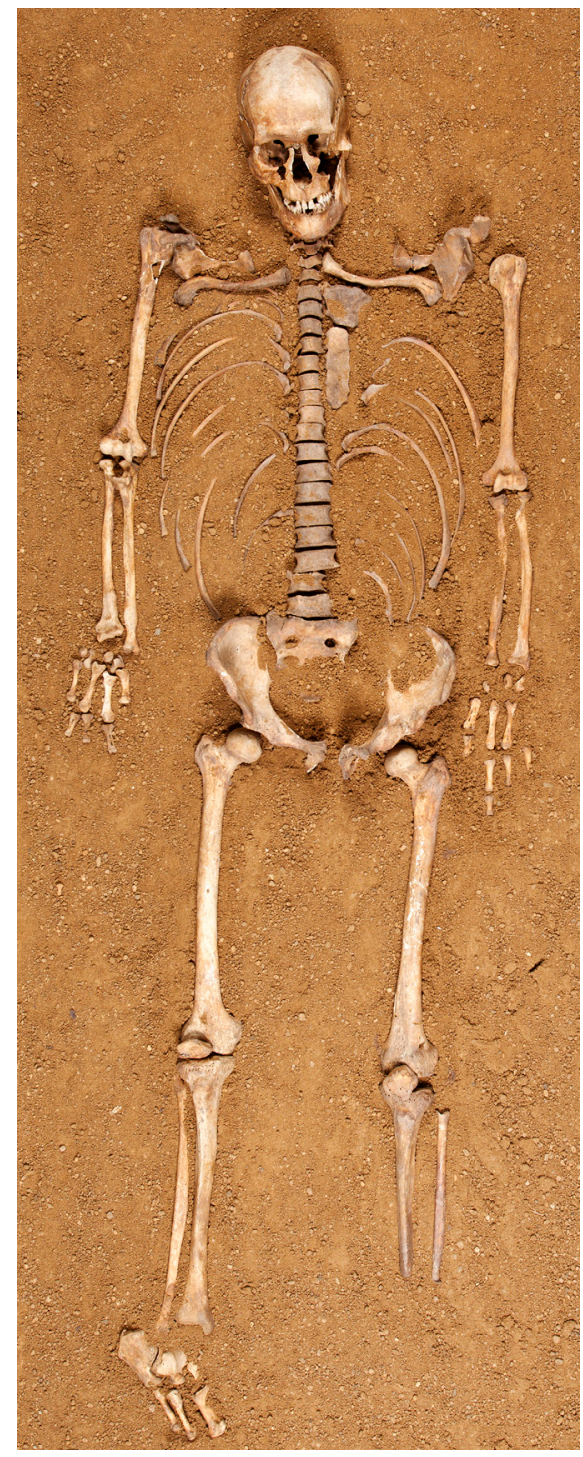

Obr. 38. Kostra velkomoravského bojovníka s amputovanou nohou. Dobře zhojené pahýly bércových kostí vypovídají o skutečnosti, že postižený tuto operaci přežil nejméně o několik měsíců. Kromě tohoto nálezu měl ještě zhojenou zlomeninu obou pravých kostí předloktí nad zápěstím a zhojenou zlomeninu levé kosti loketní. Všechna zranění zemřelého mohla pocházet ze stejné doby. Foto: J. Vaněk. z jehož pozůstalosti svazky pocházejí. On sám pod vlivem psychických problémů ukončil svůj život tak, že si prořízl hrdlo a probodl srdce. Pohnutý byl i osud zápasníka Gustava Frištenského. Masivní palcáty se šesti kovovými hroty si nechal zhotovit jako zbraň na ochranu vlastní rodiny. Zda byly jedinečné dýky ze starší doby bronzové nalezené v Kozích hřbetech používány jako zbraně, či se jednalo o rituální předměty, je dodnes nezodpovězenou otázkou.

Na kostře velkomoravského bojovníka z pohřebiště v Mikulčicích, datovaného do 9.-10. století, je zřetelný stav po amputaci levé nohy nad kotníkem, stejně jako zhojené zranění zlomeniny obou pravých kostí předloktí nad zápěstím a zhojená zlomenina samotné levé kosti loketní (obr. 38). Ta nejčastěji vzniká jako obranná při nastavení předloktí do rány útočníka. Jasnou smrtící zbraní byl hrot kuše, dodnes uchovaný v lebce třiceti- až čtyřicetiletého muže, nalezeného při archeologickém výzkumu Hradce Králové. Pravděpodobně byl obětí husitských válek. Rovněž z 15. století pochází unikátní pavéza s vyobrazením boje Davida s Goliášem. Chlapec David poráží pouhým prakem plně vyzbrojeného obra Goliáše (obr. 37).

Doklady ukončení válek jsou portrét náčelníka Harawira Te Mahikai, zřejmě jednoho ze signatářů tzv. Smlouvy z Waitangi, která upravovala vztahy mezi Maory, tj. původními obyvateli Nového Zélandu, a britskou korunou; či pero, kterým byla podepsána kapitulace německých vojsk v Praze po skončení 2 . světové války 8. května 1945. Dvojbusta od Otakara Švece zachycuje hvězdy Osvobozeného divadla Jiř́ího Voskovce a Jana Wericha, kteří před 2. světovou válkou statečně formulovali protifašistické názory, a tak museli na začátku roku 1939 emigrovat.

Nejznámějšími symboly míru jsou dýmka míru a holubice. Vedle náboženských obřadů se dýmky kouřily při př́ležitosti významných společenských či politických událostí, uzavírání obchodních dohod či právě na znamení míru. Právě díky poslední jmenované funkci jsou známé jako dýmky míru. Dýmku získal od Dakotů darem Vojta Náprstek v roce 1856. Holubici dle návrhu Pabla Picassa vytvořil francouzský medailér André Lavrillier pro medaili Mezinárodní ceny míru. Světová rada míru byla založena v roce 1950 ve Varšavě. V letech 1950-1955 udělila celkem dvacet devět Mezinárodních cen míru, mezi nimi i vystavenou medaili. Udělena byla in memoriam Juliu Fučíkovi za knihu Reportáž, psaná na oprátce. 


\section{Pokrok a zánik}

„Není to ten nejsilnější, kdo přežije, ani ten nejinteligentnější, ale ten, kdo se dokáže nejlépe přizpůsobit." (Charles Darwin)

Pokrok a zánik často přicházejí společně, a tak může i jeden jediný předmět vyprávět historii jak pokroku a poznání, tak zániku a smrti.

Takovými předměty, které v sobě spojují obojí, jsou např́klad anatomický model hlavy pro výuku mediků zhotovený částečně ze skutečné lidské lebky; urna s popelem Vojty Náprstka nebo předměty spojené s vědou a vědci s tragickými osudy.

Vojtěch Náprstek byl pokrokový muž $\mathrm{v}$ řadě ohledů a moderně jednal i v záležitosti svého pohřbu. Přál si kremaci, jejímž byl propagátorem. Vlastní kremaci si musel objednat v německé Gotě, protože rakousko-uherská katolická monarchie ji nepovolovala. Ozdobná kovová schránka od sochaře Josefa Maudera nese nápis z pera Julia Zeyera: „Co z těla zbylo, snadno se vejde $v$ nádobu malou. Srdce jeho velké přeci však nosilo v sobě celý svět." Náprstek si dokonce přál, aby urna byla vystavena (obr. 39).

Dramatický osud jedné ženy a její rodiny symbolizují exempláře z entomologických sbírek. Tyto polopouštní krasce totiž sbírala česká lékařka Vlasta Kálalová Di Lotti, která zareagovala na výzvu zakladatele entomo-

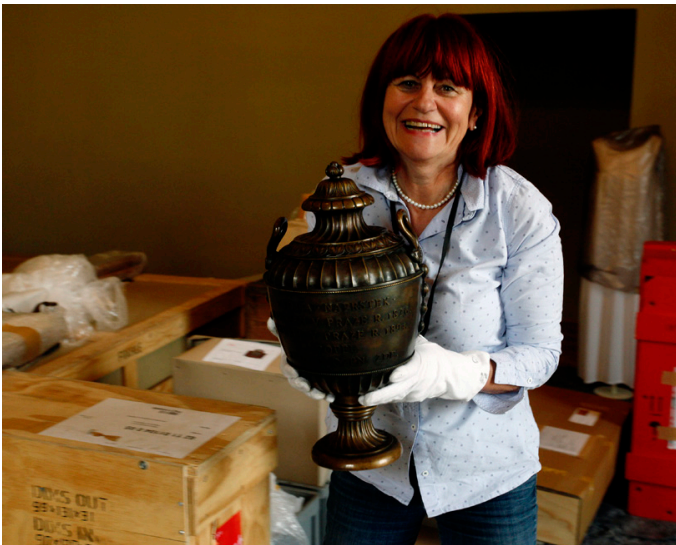

Obr. 39. Eva Dittertová připravuje k instalaci schránku s popelem Vojty Náprstka. Sám Náprstek si vystavení své urny v expozicích přál, byl totiž propagátorem kremace, $v$ té době na našem území nepovolené. Foto: J. Vaněk. logického oddělení Jana Obenbergera a posílala sběry z Bagdádu do Národního muzea. Její osud však poznamenala horečka dengue, která ji přiměla k návratu do Čech, kde v poslední den 2. světové války ustupující němečtí vojáci zavraždili jejího muže i obě děti.

Tragický konec potkal i kustoda zoologických sbírek Augusta Carla Josepha Cordu a autora vystavené kresby muchomůrky červené (obr. 41). Tento geniální pozorovatel a kreslír̆, celosvětově považovaný za jednoho ze zakladatelů vědecké ilustrace, zahynul za dodnes nevysvětlených okolností, když se vracel lodí Victoria z expedice v Texasu.

Kuriozitou mezi vystavovanými předměty je památka na smrt Miroslava Tyrše, jednoho ze zakladatelů tělovýchovné organizace Sokol. Kámen z řeky, kde v srpnu roku 1884 utonul, byl dovezen do Prahy a umístěn na bohatě vyřezávaném dřevěném podstavci. Po smrti jeho manželky byla v roce 1937 celá rodinná pozůstalost věnována muzeu.

Neméně dramatický osud souvisí i s lihovým preparátem vozhřivky (obr. 40). Toto vysoce nakažlivé infekční onemocnění, které je dnes ve světě díky antibiotikům a př́ísným veterinárním předpisům téměř neznámé, mělo po celém světě mnoho obětí, u nás především během 1. světové války (souviselo to s konzumací koňského masa). Tento konkrétní exemplář pochází z roku 1924, kdy došlo k „věrovanské tragédii“. Sedlákovi, který si od armády koupil valacha, zemřeli na nákazu dvě nevlastní děti a čeledín. Infekci podlehl i veterinářr, který pitval koně, a patolog, který pitval veterináře. Poslední obětí vozhřivky se nepřímo stala veterinářova snoubenka, která spáchala sebevraždu.

Lidskou krutost a bezmeznou hloupost zastupují preparáty živočišných druhů, které vyhubil člověk. Jedním je alka velká, která ještě ve středověku obývala oblast od Kanady po Skandinávii a byla vyhubena v 19. století. V Národním muzeu jsou uloženy dva exempláře, 
z nichž je jeden světovou raritou, má totiž skvrnu mezi okem a zobákem hnědě zbarvenou. Druhým je vakovlk, masožravý vačnatec, jehož poslední exemplář uhynul $\mathrm{v}$ naprosto nevyhovujících podmínkách roku 1936 v zoo v australském Hobartu. Tato vycpanina byla do Národního muzea zakoupena za 15 liber od firmy Frank v Londýně,

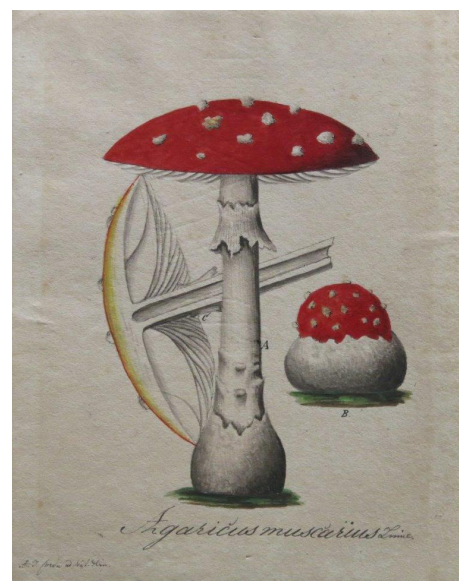

Obr. 40. Obrázek muchomůrky červené od prírodovědce a kreslíre A. C. J. Cordy.

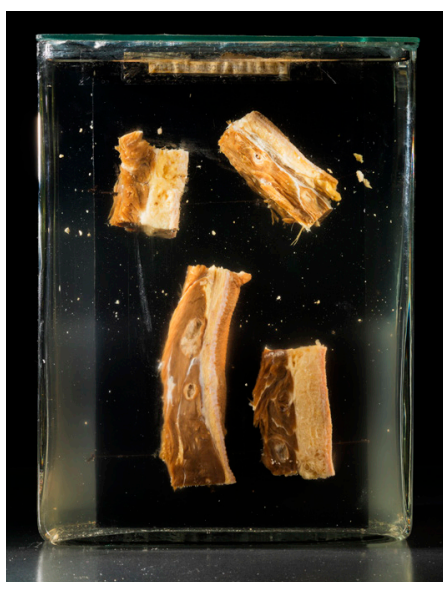

Obr. 41. Lihový preparát se zánětlivými ložisky vozhřivky. Foto: M. Frouz. nemá však původní zuby, jedná se pravděpodobně o zuby liščí nebo psí. Úplně poprvé v historii muzea je vystaven zobák vyhynulého dronta mauricijského (blboun nejapný), který kdysi žil na dvoře Rudolfa II.

V roce 1963 zachránilo Národní muzeum deset exemplářů rakousko-uherských vyznamenání, vyřazených z fondů zámku Konopiště a určených k roztavení ve Státní zkušebně pro drahé kovy. Ukázalo se, že všechna tato vyznamenání měl na své uniformě následník rakouského trůnu František Ferdinand d'Este v okamžiku, kdy ho v Sarajevu smrtelně postřelil srbský atentátník Gavrilo Princip. Arcivévoda, zasažený do krční tepny, vzápětí svému zranění podlehl. Dodnes jsou na vyznamenáních patrné stopy zaschlé krve.

Symbol pokroku zde zastupují například první vydání česko-německého slovníku Josefa Jungmanna, základní dílo českého národního obrození; dvoužárovková elektrická stolní lampa s bronzovou sochou z uměleckého pokoje herečky Marie Hübnerové (Moser, začátek 20. století), jejíž používání bylo možné díky elektrifikaci Prahy; mikroskop Jana Evangelisty Purkyně s barokně profilovaným stativem; spolkový pamětní dvoutolar z roku 1857, připomínající zprovoznění jedné z nejvýznamnějších železnic na kontinentě z Vídně do Terstu; či obraz Společná cesta do vesmíru od Jaromíra Schoře, zachycující velitele kosmické lodi SOJUZ 28 Alexeje Alexandroviče Gubareva a kosmonauta-výzkumníka Vladimíra Remka.

\section{Kř̀hké a věčné}

„...Louis C. Tiffany, malír cestující ke středomořským břehům, se nadchl pro skvělé práce ze skla Řekủ a Římanů, jež v dnešní době půda zase vrací zpátky. Když se takové věci zalíbí nějakému Evropanovi, koupí je a vystaví v muzeu. Když se zalíbí Američanovi, postaví si tavicí pec, začne hledat lidi schopné vyrobit něco podobného a sám se o to snaží ze všech sil. Louis C. Tiffany jednal jako Američan. A měl úspěch." (Adolf Loos: Rozhledy uměleckých řemesel II. Řeči do Prázdna)

Téma je inspirováno nadčasovou jemností a krásou (obr. 42, 43). Jeho ústředním exponátem jsou svatební šaty rakouské arcivévodkyně Marie Luisy. Ta se v roce 1810 nedobrovolně provdala za císaře Napoleona I. Bonaparta, nepřítele svého otce - rakouského císaře a posledního císaře Svaté říše římské Františka. Útěchou jí měla být luxusní svatební výbava, jejíž součástí byly i tyto empírové šaty.

Empírový styl vychází z antiky, kterou v tématu reprezentuje busta římského císaře Marca Aurelia a mramorové torzo krásné římské bohyně Venuše. Torzo je římskou kopií he- 


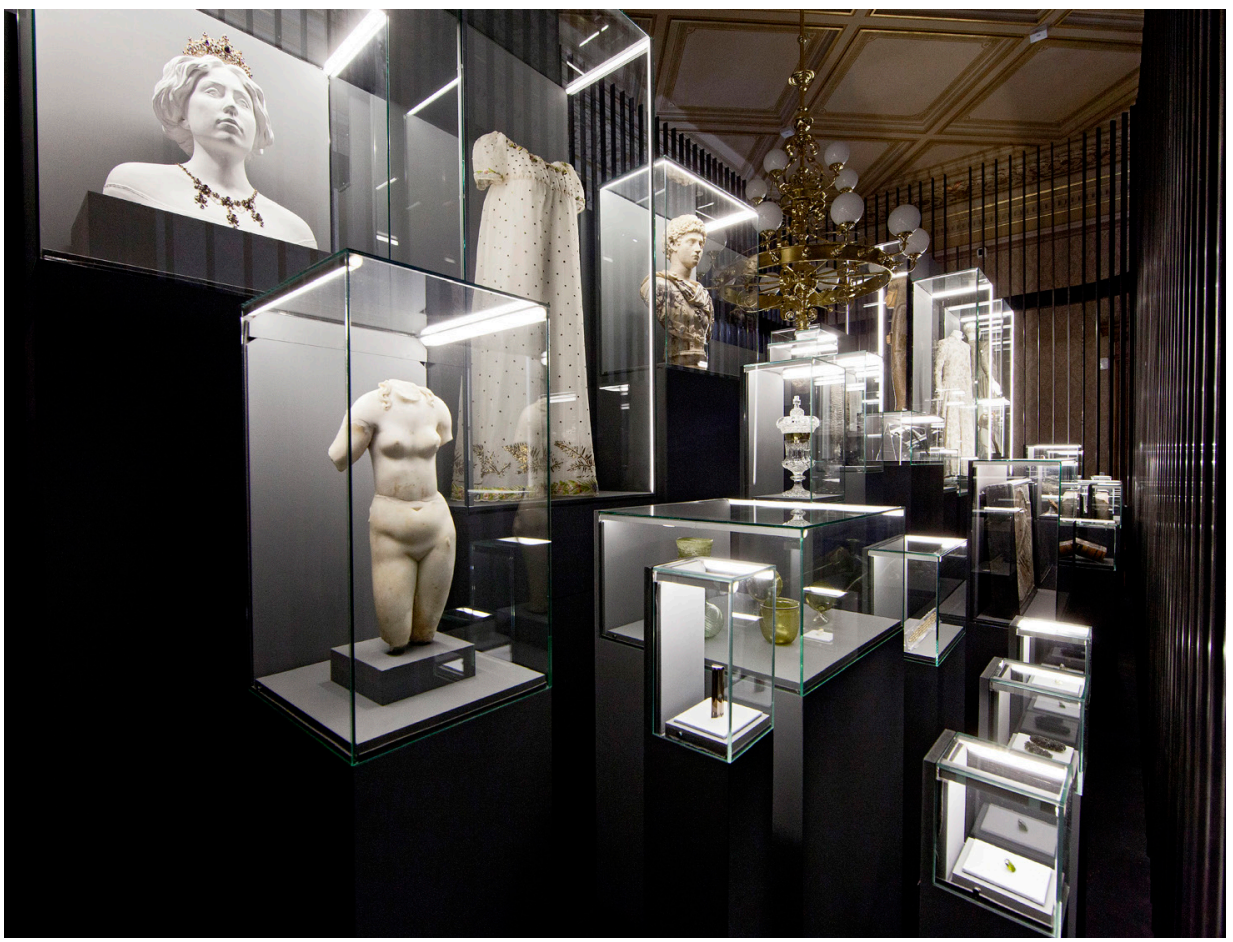

Obr. 42. Pohled do tématu Křehké a věčné. Foto: J. Vaněk.

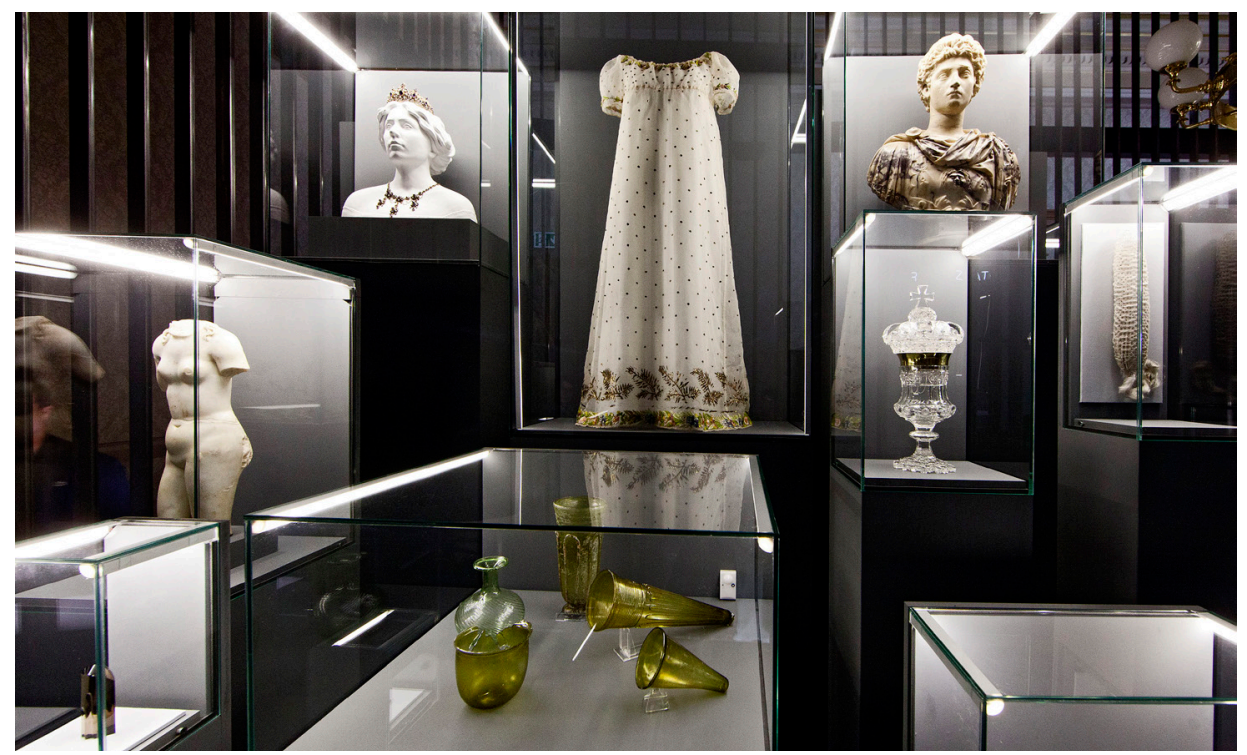

Obr. 43. Na fotografii jsou (zleva) zachyceny tyto předměty: fantazijní brus záhnědy, torzo nahé ženy (Venuše) z 2. století, šperky z pozůstalosti Emy Destinnové, antické nádoby z germánských hrobů, svatební šaty Marie Luisy, broušený pohár vyrobený pro Josefa Jungmanna, busta s hlavou Marka Aurelia a křehká schránka mořské houby. Foto: J. Vaněk. 
lénistického originálu Afrodité a jedná se o typ označovaný jako Pudica, tj. cudná. Venuše byla bohyní krásy, smyslnosti a lásky. Po ní bývá jako „Venušin koš“ označována křehká křemičitá mořská houba vzhledu jemné krajkoviny. Ta pochází z mořských hlubin poblíž Japonska. Venušin koš symbolizuje po své jmenovkyni lásku. V Japonsku jsou sušené Venušiny koše spolu s jejich korýšími obyvateli předávány jako svatební dar a mají tak symbolizovat rčení „dokud nás smrt nerozdělí".

Císařovniny hedvábné šaty svou jemnou barevnou výšivkou esteticky souznějí i s vystavenými vzácnými drahokamy a výšivkou provedenou zlatou lamelou i se zlatým pásem z Opařan. Vzácný šperk z doby halštatské představuje subtilní zlatý plíšek po celé délce zdobený geometrickým ornamentem. Je otázkou, zda se jednalo skutečně o pás, diadém, či záušnici. Smysl diadému a náhrdelníku slavné operní divy Emy Destinnové je naopak jasný. „Božská Ema“ si soubor šperků pořídila v Budapešti. Soupravu používala při nejslavnostnějších příležitostech a také při koncertním vystupování. Novorenesanční tvarování šperku odkazuje k principu návratů a opakování. Šperky jsou osazeny ametysty, indickými granáty a také pravými perlami.

Drahokamy navzdory své tvrdosti a trvanlivosti působí stejně křehce jako sklo. Mezi to vystavené patří působivé vltavíny, pozdně antické skleněné nádoby nalezené v germánských hrobech a luxusní skleněný pohár pro Josefa Jungmanna, vyrobený v harrachovských sklárnách v roce 1836. Některé drahokamy jsou zajímavé svými brusy. Vystavená záhněda má fantazijní brus a hmotnost 390 karátů, unikátní brus má i aragonit z Hořence o váze 70 karátů. Z nejslavnějšího evropského naleziště v Kozákově v Podkrkonoší pochází olivín, nalezený při větším nálezu olivínů v roce 1910.

\section{Závěr a poděkování}

Projekt takového rozsahu, v tak komplikovaných podmínkách probíhající rekonstrukce Historické budovy Národního muzea a v tak krátkém čase by nemohl být nikdy uskutečněn bez práce velmi širokého týmu. Na výstavě se podílelo více než sto kurátorů, prakticky všichni restaurátoři, fotografové, správci depozitářủ a mnoho dalších.

Mimořádné předměty vzbudily i mimořádný zájem veřejnosti, který byl částečně dán i tím, že opravená budova byla do konce roku 2018 zpřístupněna zdarma. Fronta se tak táhla kolem historické budovy až $\mathrm{k}$ podchodu na Vinohrady. Reakce lidí byly plné nadšení $\mathrm{z}$ rekonstruované budovy a muzejních pokladů. Oceňovali poslech hudby ve sluchátkách. Kladně hodnotili čtivost a př́stup $\mathrm{k}$ popiskům. Názory na výstavní prezentaci se různily. Dalo by se říci, že způsob vystavení v mř́ízových trezorech rozdělil návštěvníky na dvě poloviny, z nichž jedna je vnímala jako moderní, inovativní, i když poněkud neobvyklý způsob instalace a druhá jako překážku, bránící jim $\mathrm{v}$ těsném přístupu $\mathrm{k}$ předmětům.

Možná za sto let se naši potomci dočkají $\mathrm{k}$ dalšímu výročí podobné výstavy. Věříme, že i když se sbírky budou stále rozrůstat, „našich“ dvě stě předmětů, možná

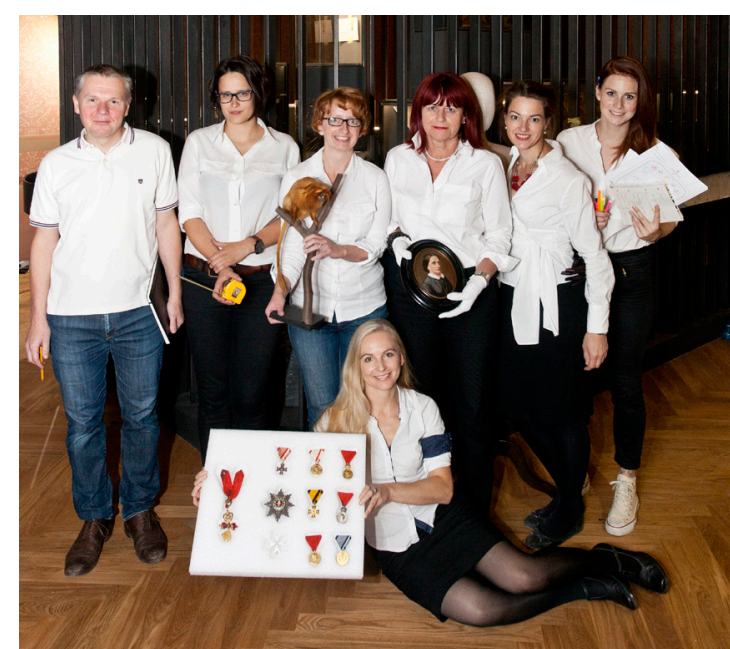

Obr. 44. Výstavní tým, zleva: Jáchym Šerých, Emília Jarošová, Jiřina Dašková, Eva Dittertová, Miroslava Burianová, Kateřina Kočí, sedící: Lucie Kodišová. Foto: J. Vaněk. 
doplněných o dalších sto, bude stále patřit k tomu nejvýznamnějšímu, co Národní muzeum opatruje, a pevně doufáme, že se do jeho Historické budovy předměty opět vrátí. Historická budova je vlastně chrámem vědy, umění a historie. Když na výstavě v tomto svatostánku návštěvníky líbají múzy, je to nejvyšší důkaz smyslu muzejní práce.

\author{
„V rámci muzejního fondu \\ vystavili anakondu. \\ Zeptal se mne malý Tonda: \\ Neobživne anakonda? \\ Bojí se jí, nebot'ví že, \\ proklouzla by skrze mř́že!" \\ (zápis z návštěvní knihy)
}

\title{
Tiráž
}

Námět výstavy: Michal Lukeš

Koncept výstavy: Miroslava Burianová

Autorky: Miroslava Burianová, Jiřina Dašková, Eva Dittertová, Lucie Kodišová

Kurátorka výstavy: Eva Dittertová

Supervize: Michal Stehlík

Odborná spolupráce: Helena Heroldová, Marek Junek, Markéta Kabelková, Jiří Košta, Jan Sklenář, Lubomír Sršeň

Produkce výstavy: Kateřina Kočí, Martin Musil, Tereza Lišková

Adjustace předmětů: Dana Szemályová, Veronika Šulcová, Irena Straková

Architektonické a interiérové řešení: ilex design | Emília Jarošová

Grafický design: Jáchym Šerých

Realizace výstavy: LN - Design, s.ro.; DKset, s.r.o.; Kurel, s.r.o.; Grafpro, s.r.o.; NEONY SIGN, a. s.

Práce s veřejností: Kristina Kvapilová, Šárka Bukvajová

Marketing: Lea Matvijová, Eva Hořejší

Překlad: Pygmalion, s.r.o.

Jazykové korektury: Jana Kárová, Jaroslav Richter

Restaurování předmětů: Martin Fořt, Romana Kozáková, Adéla Skoupá, Dana Szemályová, Veronika Šulcová, Olga Trmalová, Markéta Klímová

Instalace: Zuzana Němcová, Alena Vrbová, Blanka Škodová, Věra Kabešová

Kresby ikon: Veronika Plátková

Kresby: Lenka Káchová, Jan Sovák

Fotografování: Martin Frouz, Lenka Káchová, Alžběta Kumstátová, Lenka Macháčková, Eva Rydlová, Olga Tlapáková, Jiř̌́ Vaněk

Administrace: Petr Brůha, Katarína Garčárová, Petra Korandová, Petra Štefcová, Silvie Vančurová

Spolupráce na audio: Petr Benda, Eva Dittertová, Jan Sovák, Emanuele Gadaleta, Martin Sekera, Michal Stehlík, Richard Šípek, Marek Junek; Bystrouška, spol. s r.o.

Technická spolupráce: Petr Pufler, Tomáš Pilarski

Poděkování: Peter Balog, Štěpánka Běhalová, Milena Běličová, Petr Benda, Sandra Bergmannová, František Bouda, Petra Burdová, Hana Copková, Viktoria Čist'akova, Jan Dašek, Petr Dolejš, Jaroslav Ďuriš, Boris Ekrt, František Fürbach, Emanuele Gadaleta, Jiří Hájek, Jaroslav Hlaváč, Jan Holec, Zuzana Holečková, Luděk Hudec, Marek Jantač, Hanuš Jordan, Marek Junek, Gabriela Jungová, Karel Kadeřábek, Lenka Káchová, Karfusová Veronika, Michal Klacek, Petra Korandová, Jiří Košta, Alena Krejčová, Karel Křenek, Jan Kříženecký, Vítězslav Kuželka, Jiří Kvaček, Milan Libertín, Kateřina Lorencová, Lenka 
Macháčková, Petr Mašek, Kateřina Maýrová, Jiří Mlíkovský, Olga Mojžíšová, Jiří Moravec, Pavel Muchka, Zdeněk Mužík, Vlastimil Novák, Jan Novotný, Pavel Onderka, Miroslav Pastrňák, Eva Paulová, Adéla Pečlová, Eliška Peterková, Martin Plitz, Vít Pokorný, Luboš Polanský, Dagmar Pospíšilová, Dana Přenosilová, Petr Přibyl, Šárka Rámišová, Radka Rosenbaumová, Milena Secká, Jiř́i Sejkora, Martin Sekera, Lukáš Sekerka, Ema Součková, Lubomír Sršeň, Matěj Stahl, Eleonóra Stanková, Helena Svobodová, Lenka Šaldová, Otakar Šída, Ludmila Škrabáková, Evženie Šnajdrová, Dagmar Štefancová, Petra Štefcová, Blanka Švecová, Ondřej Táborský, Monika Tauberová, Petr Tíkal, Jolana Tothová, Vojtěch Turek, Jana Tvrzníková, František Vacek, Lenka Váchová, Martin Valent, Jaromír Váňa, Veronika Vejvodová, Dalibor Velebil, Petr Velemínský, Monika Veverková, Libor Vodička, Jana Vojtěšková, Milan Voříšek, Vlastimil Vrtal, Martina Vyšohlídová, Jan Wagner, Klára Woitschová; Lobkowicz Collections, o.p.s.; Muzeum Jindřichohradecka; Národní filmový archiv; Národní památkový ústav, ÚPS v Českých Budějovicích; Státní okresní archiv Písek; Státní oblastní archiv Třeboň; Vojenský historický ústav Praha

\section{Literatura}

Burianová M., 2018: Jedinečné předměty - překvapivý kontext. - Dějiny a současnost č. 10, 2018, 36-37.

Dašková J., Kodišová L., 2018: Osobnosti Národního muzea. - Dějiny a současnost 9/2018, 32-33.

Kodišová L., Dašková J. 2019: „...aby po svém obsahu bylo nejen přírodopisné“ Příroda a dějiny v Národním muzeu. - Dějiny a současnost 1/2019, 36-37.

Šprinclová Z., 2019: Kde se vzaly poklady Národního muzea? - Lidé a země 68, 1: 103-107.

\section{Summary}

\section{"Manhattan skyline" in the National Museum?}

Miroslava Burianová, Jiřina Dašková, Eva Dittertová \& Lucie Kodišová

In 2018, 200 years had passed since the founding of the National Museum, and 100 years since the founding of Czechoslovakia. The National Museum honored both of these anniversaries with exhibitions: the Czechoslovak Exhibition and the $2 \times 100$ Exhibition; this article addresses the second of those. The disparate range of objects was presented in a new and surprising context, which reflected the diversity of exhibits - historical, scientific and artistic objects, not only from Czechia, but from around the world. For many visitors, the architecture of the exhibition itself was certainly unexpected: the "Manhattan skyline" concept. The article is devoted not only to the selection of exhibits, but also to a behind-the-scenes look at the museum's work: how the exhibition was created in the challenging conditions of the historical building installation.

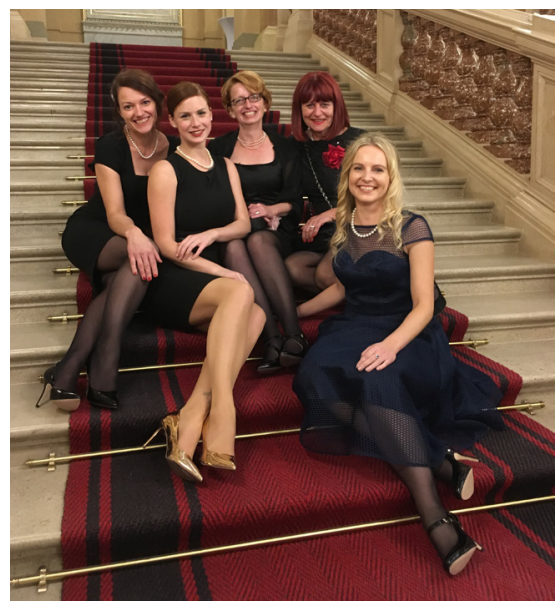

Obr. 45. Autorský tým během vernisáže k otevření zrekonstruované Historické budovy Národního muzea . Foto: H. Kočí. 